\title{
Subsidiary autonomy in transition economies: Italian SMEs in Central and Eastern European countries ${ }^{*}$
}

\author{
Alessia Pisoni, Luciano Fratocchi, Alberto Onetti ${ }^{* *}$
}

This paper aims at shedding new light on the variables that indicate the level of autonomy of subsidiaries of internationalizing companies. Specifically, we examine subsidiaries located in the transition economies of Central and Eastern European Countries (CEECS). We identified a sample of 72 subsidiaries of micro, small and medium-sized Italian companies, and we assessed the impact of three variables on the subsidiary's autonomy: the size; the strategic aim in the local market (market seeking or cost reduction); and the degree of economic development of the local country. Our results suggest that subsidiary's autonomy reflects local country characteristics, but not the economic development. Our findings also show that subsidiaries looking for penetrating the local market are generally more autonomous than the ones pursuing costcutting strategies.

Dieser Artikel untersucht zentrale Einflussfaktoren der Selbständigkeit von Tochterunternehmen anhand eines Samples von 72 italienischen Tochtergesellschaften (Klein- und Mittelunternehmen) in Mittel-und Osteuropa. Die Ergebnisse zeigen, daß die Größe des Tochterunternehmens, das Gründungsziel (Gewinnung neuer Märkte oder Kostenabbau) und die wirtschaftliche Entwicklung des Auslandsmarktes die Autonomie der Tochtergesellschaft beeinflussen. Wachsende Auslandsmärkte und das Ziel der Absatzmarkterschließung führen generell zu mehr Selbständigkeit des Tochterunternehmens.

Keywords: internationalization, subsidiary autonomy

\footnotetext{
* Manuscript received: 03.04.11, Accepted: 10.12.12 (2 Revisions)

** Alessia Pisoni, Dr., Department of Economics, University of Insubria, Varese, Italy. Main research interests: International Business, Entrepreneurship, Corporate Strategy, Corporate Governance. Corresponding address: alessia.pisoni@uninsubria.it

Fratocchi Luciano, Dr., Prof., Department of Industrial and Information Engineering and Economics, University of L'Aquila, L'Aquila, Italy. Main research interests: International business, Managerial and Organizational Innovation, Supply Chain Management.

Onetti Alberto, Dr., Prof., Department of Economics, University of Insubria, Varese, Italy. Main research interests: Corporate Strategy, Entrepreneurship, Business Models for high tech and global companies, International Business.
} 


\section{Introduction}

This paper investigates the variables influencing subsidiary autonomy of Italianowned SMEs (Small and Medium Enterprises) ${ }^{1}$ located in Central and East European Countries (CEECs). The investigation adopts Björkman's definition (2003) of autonomy in the subsidiary of a multinational as the extent to which decision-making in the subsidiary occurs without interference from Headquarters. This definition is consistent with the Young and Tavares' idea that autonomy "concerns the constrained freedom or independence available to, or acquired by, a subsidiary, which enables it to take certain decisions on its own behalf" (2004: 228).

The issue of subsidiary autonomy is a weighty one for varying reasons, of which the most conspicuous are:

a. the high volume of FDI in CEECs, expecially as deriving from Italian companies;

b. the sparseness of literature on subsidiary autonomy in transition economies;

c. the inadequacy of research on the internationalization strategies of Italian SMEs', and especially those active in CEECs.

Regarding the first reason, the table in Annex 1 clearly shows that the fall of the Berlin Wall, the subsequent collapse of communist regimes in all CEECs, their transition to market economies and their definitive integration into the European Union (EU) dramatically increased the flow of foreign direct investments (FDIs) to those countries.

The flow of Italian corporate FDI to CEECs accelerated appreciably between the end of the 1980s and the beginning of the 1990s and has continued to increase. At the beginning of 2006 (when the data used in this paper were collected), CEECs were the second major destination, as defined by the number of investing companies and foreign-owned firms, and by headcounts and turnover of Italian corporate FDIs (Annex 2). More specifically, the number of Italian companies investing in CEECs was slightly less than that involved in FDI within the European Union (15 countries) and more than double that within North America. The fact that Italian corporate FDI in CEECs has mostly taken place since the ' 80 s clearly emphasizes the importance of the given geographical area. This importance is further confirmed by the average growth rate of Italian companies investing in CEECs in the 2001-2006 period; at 26.4\%, this rate was higher than any other found for the area in question, and it was double that of

We here adopt the definition of SME acknowledged by the Commission Recommendation 2003/361/EC (6 May 2003), according to which it is possible to define micro, small and medium company on the respective bases of headcount, turnover or balance sheet total (http://ec.europa.eu/enterprise/policies/sme/facts-figuresanalysis/sme-definition/index_en.htm). 
corporate FDI flows to the EU15. The total number of Italian-owned companies in the CEECs rose by $14.8 \%$ during the $2001-2006$ period, almost double the growth rate of Italian-owned companies worldwide. Moreover, Reprint Database data clearly show that Italian companies generally acquired small and medium companies, since the number of companies owned overseas increased by $14.8 \%$ while total headcount only grew by $9.4 \%$. The average turnover of all 3,052 foreign companies belonging to Italian enterprises was 7.4 million Euro, which European Commision Recommendation 2003/361/EC defined as typical of small organizations.

More recently, data from the Italian Institute for Foreign Trade (ICE 2009) clearly showed that $52 \%$ of total employees in Italian subsidiaries were in new EU countries, and that $31.8 \%$ of those employed in Eastern Europe and the Balkans (including Romania and Bulgaria) belonged to firms classified as SMEs. The same source reported that $32.2 \%$ of total sales of italian subsidiaries came form new EU countries, of which 19.4\% derived from SMEs.

As already mentioned, the existing empirical literature on subsidiary autonomy generally deals with subsidiaries located in advanced market economies; significantly less research has been undertaken on subsidiaries placed in transition economies (Männik/Varblane/Hannula 2005, 2006). This can be explained by the fact that FDIs in CEECs have been historically driven mainly by goals of cost reduction (delocalization). In such situations headquarters typically exert a tight control over subsidiaries. This assumption seems to be even more relevant in the case of Italian SMEs. As clearly showed by Mutinelli and Piscitello (1997), while FDIs in CEECs implemented by larger Italian companies are generally market seeking oriented, Italian SMEs generally are aimed at supplying raw materials or semi-finished intermediate goods. Moreover, Italian SMEs usually adopt a family-based governance system and tend to centralize all the decisions on the founding entrepreneur (Mutinelli 2001, Colarossi et al. 2008). For all these reasons, research on autonomy of the Italian subsidiaries in CEECs may have not attracted the interest of scholars. On the other side, recent studies point out that strategic objectives of Italian firms in CEECs are evolving and the "subsidiary's value chain" is progressively widening the range of performed activities (Cotta Ramusino/Onetti 2006). Based on such evidences, we decided to further analyze the degree of subsidiaries' autonomy of Italian SMEs in CEECs with the goal to identify its main drivers. Moreover, as the second reason for the current paper, this feature gathers significance in the light of Otterbeck's affirmation that "we may see subsidiary autonomy as one reflection of certain, as yet not well defined, country characteristics" (1981: 338). That said, the literature review section will clearly show that findings on elements influencing subsidiary autonomy were often contradictory, especially when variables concerning subsidiaries' features were considered (e.g., subsidiary size or "age", and level of local market economic 
development. The analysis of these variables as they affect subsidiary autonomy within the CEEC context could well provide interesting insights

The third reason for this paper is the inadequacy of the literature on Italian SME internationalization strategies, especially with regard to CEECs. After initial contributions by Mutinelli and Piscitello $(1997,1998)$, this topic attracted very little attention. On the basis that $58.7 \%$ of total companies operating in Italy are classified as micro, and $40.7 \%$ as small firms (Banca d'Italia 2006), this gap is glaringly important.

The paper is structured in four main sections. The first comprehensively reviews the literature on both subsidiary autonomy and transition economies. On the basis of this theoretical context, the second part develops three research hypotheses related to subsidiary size, strategic aims and local country economic development. Section 3 presents the research methodology and discusses the most prominent features of responding companies. Finally, Section 4 presents and debates the research results and outlines the managerial and research implications of the paper.

\section{Literature review and hypotheses development}

\section{Literature review on subsidiary autonomy}

The management of multinational companies (MNCs) - especially of large ones - has attracted the interest of scholars for many decades. Attention to subsidiaries over the same decades has been sparse. As correctly noted by Birkinshaw and Hood (1998), research on MNC subsidiary management only started at the end of the '70s. A founding research project in this study area is that entitled "Managing the relations between headquarters and foreign operations in multinationals", which was produced out by the Institute of International Business at the Stockholm School of Economics (see, among others, Picard 1980; Otterbeck 1981; Hedlund 1981; Garnier 1982). Since the beginning of the ' $80 \mathrm{~s}$, a lot of research has targeted widely varying issues inherent to MNC subsidiary management. Said research identifies three main areas of interest (Birkinshaw/Hood 1998):

a. headquarters-subsidiary relationships, which analyzes aspects of dyadic relationships between the subsidiary and the headquarters on the assumption of a hierarchical point of view that conceptualizes local subsidiaries as controlled by the headquarters;

b. the subsidiary's role, analysis of which starts from the founding work by White and Poynter (1984) on Canadian subsidiaries, and continues with a considerable number of publications (see, among others, Bartlett/Ghoshal 1986; D’Cruz 1986; Ghoshal/Nohria 1989; Jarillo/Martinez 1990; Gupta/Govindarajan 1991; Birkinshaw/Morrison 1995; Taggart 1997). 
Overall, this research conceptualizes subsidiaries as nodes within a complex network of relationships, both inside and outside the MNC (see, among others, Hedlund 1981, 1986; Bartlett/Goshal 1989; Forsgren 1989,1990; Bartlett et al. 1990; Ghoshal/Bartlett 1991; Forsgren et al. 1991, 1992, 1995; Forsgren/Johanson 1992; Snow et al. 1992; Holm et al. 1993; Nohria et al. 1994; Forsgren/Pedersen 1998);

c. the subsidiary's development, i.e. how and why activities managed by the subsidiary change over time. This stream of research also builds on a conceptualization of MNCs as networks, but it also takes issues such as resources and capabilities into account (see among the others, Birkinshaw/Hood 1998; Holm/Pedersen 2000).

Of these three areas of interest, the most relevant to this paper is the first, since several scholars belonging to it focused on variables that explain the linkages between headquarters and subsidiaries, i.e. on the bases of subsidiary autonomy.

Subsidiary autonomy interests international business scholars because it raises, and is influenced by, varying and important issues. Primarily:

a. faced with the considerable risks (in the form of tangible and intangible investments) inherent to overseas subsidiaries, company headquarters generally and instinctively aim to centralize decision-making activities in order to maintain strict control over the overall business, which in turn implies restrictions on subsidiary autonomy;

b. at the same time, the uncertainties inherent to operating in foreign markets can induce subsidiary autonomy. The uncertainties mainly regard the absence of knowledge about the local socio-economic environment. By accessing, gathering and processing sources of information, local subsidiaries can reduce uncertainty and thus achieve greater autonomy;

c. simultaneously, local governments want local subsidiaries to acquire a substantial role within the internationalized company, since such subsidiaries will foster local economic development (Doz 1986);

d. moreover, in some industries, adaptation to local needs and local citizenship are critical sources of competitive advantage.

The increasing importance of studies on subsidary autonomy is now widely and soundly established (see, inter alia, Brooke 1984; Young/Tavares 2004). The fact that autonomy is now recognized both as a prerequisite and as a desirable result of subsidiary development only compounds the topic's importance (Birkinshaw/Morrison 1995; Forsgren et al. 1992; Birkinshaw/Hood 1998; Hood/Taggart 1999; Young/Tavares 2004; Birkinshaw/Lingblad 2005). Birkinshaw and Hood (1997) also argued that autonomy was beneficial not just to the subsidiary but to the headquarters as well. 
A deluge of empirical research on subsidiary autonomy has identified several variables that may influence the development of autonomy. Table 1 summarizes the most important of these variables. However, and not surprisingly, the literature is highly divergent, not least because, as Singh (1981) noted, the data collected is often qualitative and sometimes even subjective. Another feature that impedes convergence in the literature is that subsidiary autonomy is not necessarily an explicit corporate issue; as Otterbeck notes, "MNC management do not sit down and decide on how much autonomy they shall grant their foreign subsidiaries. They decide on other things. These decisions and some other characteristics of the way the day-to-day relationships are handled together form a pattern which we may call autonomy. Therefore we may see subsidiary autonomy as one reflection of certain, as yet not well defined, country characteristics" (1981: 338).

Table 1 Subsidiary-specific variables deemed to explain autonomy

\begin{tabular}{|c|c|c|}
\hline Variable & Authors & $\begin{array}{c}\text { Correlation with subsidiary } \\
\text { autonomy }\end{array}$ \\
\hline \multirow{7}{*}{$\begin{array}{l}\text { Percentage of subsidiary } \\
\text { social capital owned by } \\
\text { the headquarters }\end{array}$} & Alsegg 1971 & Negative \\
\hline & Youssef 1975 & Negative \\
\hline & $\begin{array}{l}\text { Garnier/Osborn/Galicia/Lecon } \\
1979\end{array}$ & Negative \\
\hline & Hedlund 1981 & Not clearly definite \\
\hline & Garnier 1982 & Negative \\
\hline & Welge 1981 & Negative but limited \\
\hline & Gates/Egelhoff 1986 & Negative \\
\hline \multirow{3}{*}{$\begin{array}{l}\text { Economic development } \\
\text { of subsidiary country }\end{array}$} & Hedlund 1981 & Not clearly definite \\
\hline & $\begin{array}{l}\text { Männik/Varblane/Hannula } \\
2005\end{array}$ & Positive \\
\hline & Edwards/Ahmand/Moss 2002 & Positive \\
\hline Psychic distance & Hedlund 1981 & None \\
\hline Geographic distance & Welge 1981 & Positive \\
\hline $\begin{array}{l}\text { Degree of uncertainty } \\
\text { with respect to the local } \\
\text { environment }\end{array}$ & Hedlund 1981 & Positive but not strong \\
\hline $\begin{array}{l}\% \text { of purchase from } \\
\text { headquarters }\end{array}$ & Hedlund 1981 & Negative \\
\hline$\%$ of subsidiary export & Hedlund 1981 & Positive \\
\hline $\begin{array}{l}\text { Technology transferred } \\
\text { from the headquarters }\end{array}$ & Hedlund 1981 & Scarce but positive \\
\hline
\end{tabular}




\begin{tabular}{|c|c|c|}
\hline \multirow[t]{13}{*}{ Subsidiary size } & Alsegg 1971 & Positive \\
\hline & Youssef 1975 & None \\
\hline & Picard 1978 & Negative \\
\hline & Hedlund 1981 & $\begin{array}{l}\text { Positive but weak and only for } \\
\text { fairly small firms. In the case of } \\
\text { large subsidiaries, negative }\end{array}$ \\
\hline & Negandhi/Baliga 1981 & Positive \\
\hline & Welge 1981 & Positive \\
\hline & Garnier 1982 & Positive but weak \\
\hline & Young/Hood/Hamill 1985 & Negative \\
\hline & Gates/Egelhoff 1986 & Positive \\
\hline & Harzing 1999 & Positive \\
\hline & Hood/Taggart 1999 & $\begin{array}{l}\text { Positive albeit not statistically } \\
\text { significant for size in terms of } \\
\text { employment } \\
\text { Negative and significant for size } \\
\text { in terms of sales }\end{array}$ \\
\hline & Johnston/Menguc 2007 & $\begin{array}{l}\text { Existence of an inverted-U } \\
\text { shaped relationship between } \\
\text { subsidiary size and subsidiary } \\
\text { autonomy }\end{array}$ \\
\hline & Khandwalla 1973 & Negative \\
\hline \multirow{3}{*}{$\begin{array}{l}\text { Degree of concentration } \\
\text { in the subsidiary's } \\
\text { market }\end{array}$} & De Bodinat 1975 & Positive but weak \\
\hline & Hedlund 1981 & Positive but weak \\
\hline & Alsegg 1971 & Positive \\
\hline \multirow[t]{8}{*}{ Subsidiary "age" } & Youssef 1975 & $\begin{array}{l}\text { Positive for "personal control" } \\
\text { Negative for "in direct control" } \\
\text { (e.g. managerial control systems, } \\
\text { procedure) }\end{array}$ \\
\hline & Welge 1981 & Positive but small \\
\hline & Garnier 1982 & Positive but weak \\
\hline & $\begin{array}{l}\text { Van den Bulcke/Halsberghe } \\
1984\end{array}$ & Positive \\
\hline & Young/Hood/Hamill 1985 & Not clear \\
\hline & Gates/Egelhoff 1986 & $\begin{array}{l}\text { Positive for manufacturing } \\
\text { autonomy but negative for } \\
\text { marketing one }\end{array}$ \\
\hline & Harzing 1999 & Positive \\
\hline & Hood/Taggart 1999 & Positive \\
\hline
\end{tabular}




\begin{tabular}{|c|c|c|}
\hline & Mirchandani/Lederer 2004 & $\begin{array}{l}\text { Positive for specific companies' } \\
\text { activities }\end{array}$ \\
\hline & Hedlund 1981 & Positive \\
\hline Subsidiary market share & Alsegg 1971 & Positive \\
\hline \multirow[t]{7}{*}{ Subsidiary performance } & Hedlund 1981 & Positive but limited \\
\hline & Hedlund 1981 & Negative \\
\hline & Birkinshaw/Morrison 1995 & $\begin{array}{l}\text { high and low (but not medium) } \\
\text { levels of autonomy lead to good } \\
\text { performance }\end{array}$ \\
\hline & $\begin{array}{l}\text { McDonald/Warhurst/Allen } \\
2008\end{array}$ & $\begin{array}{l}\text { limited evidence for positive } \\
\text { relationships between some types } \\
\text { of autonomy and } \\
\text { performance. }\end{array}$ \\
\hline & Ambos/Birkinshaw 2010 & Positive \\
\hline & $\begin{array}{l}\text { Gammelgaard/McDonald/Step } \\
\text { han/Tüselmann/Dörrenbächer } \\
2012\end{array}$ & $\begin{array}{l}\text { Positive and negative, it depends } \\
\text { on host country effects }\end{array}$ \\
\hline & Chen 2011 & Positive \\
\hline $\begin{array}{l}\text { Subsidiary dependence } \\
\text { on headquarters' product } \\
\text { range }\end{array}$ & Young/Tavares 2004 & Negative \\
\hline $\begin{array}{l}\text { Political stability in the } \\
\text { subsidiary's country }\end{array}$ & $\begin{array}{l}\text { Garnier } 1982 \\
\text { Van de Bulcke/Halsberghe } \\
1984 \\
\text { Young/Hood/Hamill } 1985 \\
\text { Andersson/Forsgren } 1996 \\
\text { Harzing } 1999\end{array}$ & $\begin{array}{l}\text { Greenfield, more centralised } \\
\text { Brownfield/Merger \& } \\
\text { acquisition, more autonomous }\end{array}$ \\
\hline \multirow[t]{2}{*}{ Mode of establishment } & Young/Hood/Hamill 1985 & Positive \\
\hline & Slangen/Hennart 2008 & $\begin{array}{l}\text { Greenfield is less preferred when } \\
\text { HQ plans to grant the local } \\
\text { subsidiary considerable } \\
\text { autonomy in marketing }\end{array}$ \\
\hline
\end{tabular}




\begin{tabular}{|l|l|l|}
\hline $\begin{array}{l}\text { Pursuit of strategic aims } \\
\text { at subsidiary's local } \\
\text { market level }\end{array}$ & Eltetö 1999 & $\begin{array}{l}\text { Weak relationship between } \\
\text { subsidiary and HQ in case of } \\
\text { market-seeking investment }\end{array}$ \\
\cline { 2 - 3 } & $\begin{array}{l}\text { Petrochilos 1989 } \\
\text { Chudnovsky/Lopez/Porta } \\
1997\end{array}$ & $\begin{array}{l}\text { Autonomy is considered as a } \\
\text { prerequisite for this strategy }\end{array}$ \\
\hline $\begin{array}{l}\text { Belonging to large } \\
\text { international network(s) }\end{array}$ & Edwards/Ahmad/Moss 2002 & Positive \\
\hline $\begin{array}{l}\text { Level of information } \\
\text { owned by the subsidiary }\end{array}$ & Kobrin 1991 & $\begin{array}{l}\text { Positive } \\
\text { Industry }\end{array}$ \\
$\begin{array}{l}\text { Roth/Morrison 1992 } \\
\text { Makhija/Kim/Williamson } \\
\text { globalized industries (e.g. } \\
\text { automotive, electronics) are } \\
\text { generally less autonomous }\end{array}$ \\
\hline
\end{tabular}

Recently, Manolopoulos (2006) reviewed the concept of subsidiary autonomy and proposed three different dimensions of autonomy: assigned, earned and acquired. The first concerns the formal and legitimate authority to take decisions and is assigned by the headquarters; the second, the subsidiary life cycle and its relationship with the internal network; the third, the relationships with the external network (suppliers, customers, local government).

Within the subsidiary autonomy literature, a specific stream of research focuses on the degree of autonomy enjoyed by specific functional activities. In this regard, Hedlund (1981) states that headquarters centralize issues of a strategic nature, while operational issues are managed directly by subsidiaries. Within this perspective, he found that finance was the most strategic issue, while most operational issues are about organization and human resources. This finding concurs with that of Garnier et al. (1979), who discovered that subsidiary autonomy tends to be highest in marketing issues. Vachani (1999) found that subsidiary autonomy is greater for marketing and human resource management decisions than for R\&D and finance. More recently, Edwards, Ahmad and Moss (2002) concluded that the greater the subsidiary's knowledge ownership, the greater its autonomy becomes. It follows that autonomy is more substantial in operational areas, such as wage rates and domestic marketing. Finally, Young and Tavares (2004) demonstrated that financial management and R\&D decisions are often highly centralized, that human resource management is the least centralized, and that marketing and manufacturing lie in between.

A more structured approach was adopted by Young et al. (1985), who analysed specific decision areas rather than business functions. They found that the most centralized decisions were primarily the financial ones (target ROI, dividend and royalty policies), together with a selection of those related to marketing (namely, 
those concerning both the portfolio of existing markets and entrance to new foreign markets) and R\&D issues. Edwards et al. (2002) conceptualized these findings by proposing that integrated issues are highly centralized, whereas locally responsive issues are more decentralized. Thus, financial issues are highly integrated and affect the multinational company in its entirety. In contrast, marketing is often directed towards the local market and hence can be decentralized. HR management is dependent on local legislation, and consequently requires local operation, which in turn translates into higher specific autonomy for the subsidiary.

It should be noted that subsidiary autonomy may also be influenced by its role within the networked architecture of the multinational company. With specific respect to manufacturing activities, for instance, Gupta and Govindarajan (1991) state that if the subsidiary produces components in a vertical supply relationship with other sister units, coordination is higher, and subsidiary autonomy consequently diminishes. This notion is confirmed by Young and Tavares (2004), and has also been evidenced in the case of product mandates (White/Poynter 1984). In contrast, Martinez and Jarillo (1991) and Harzing (1999) discovered that local market-oriented subsidiaries tend to have higher autonomy.

\section{Literature review on the aims pursued by FDIs in CEECs}

International business literature on CEECs, generally focuses on the variables that prompt the localization of FDIs in the given geographical area (for a comprehensive analysis of the debate on this topic, see, inter alia, Reiljan et al. 2001). For instance, Lankes and Venables (1996) and Lankes and Stern (1998) noted a predominance of market-seeking investments over efficiency-seeking, natural resource-seeking and strategic asset-seeking FDIs. However, Lankes and Venables (1996) pointed out that the aim of FDI varies significantly on the basis of the host country's progress in economic transition. More specifically, these authors discovered that FDI projects in the transitionally more advanced countries were more likely to be export-oriented and more likely to exploit the comparative advantage of the host's economy. This, in turn, increased the headquarters' dependence on the local subsidiary and, as a consequence, the latter's autonomy. These results are consistent with Meyer's previous findings (1995) to the effect that market-seeking is the primary reason for FDI in the early stages of CEECs' transition to a market economy. According to Meyer, efficiency-seeking plays a secondary role in CEEC FDI, and only emerges if the host country offers an attractive local market. Marinov and Marinova (1999) and Pye (1997) have reached similar conclusions. Éltetö (1999) demonstrated that FDI in CEECs were aimed both at market and at cost-reduction purposes, given the relative lack of natural resources and strategic assets in the given countries. The results of several other studies (Wang/Swain 1995; Guimaraes et al. 1997; 
Holland/Pain 1998a, 1998b; Borsos-Torstila 1998; Barrell/Pain 1999; Garibaldi et al. 1999; Reiljan 1999; Ziacik 2000) are consistent despite quite large discrepancies between countries and industries.

With regard to empirical papers on Italian companies, Mutinelli and Piscitello (1997) clearly demonstrated that while FDI in CEECs is generally oriented to market-seeking, analogous activities by SMEs seek to assure the provision of raw materials or semi-finished intermediate goods (Majocchi/Onetti 2002). A more recent contribution from Majocchi and Strange (2006) clearly demonstrated that CEEC-bound Italian firms decide on location mainly on the basis of five issues: a) market size, b) market growth potential, c) availability of labour (even if not necessarily skilled), d) openness of the economy to foreign trade, e) previous investors' experience. These results broadly confirmed the findings of similar studies related to other geographical areas. Additionally, Majocchi and Strange demonstrated the importance of the trade and market liberalization variables - which are generally considered less substantial. This notion is echoed by Bevan, Estrin and Meyer (2004), according to whom FDI flows to transition economies are generally driven by features like: a) the ongoing replacement of state-owned with private businesses, b) a welldeveloped banking sector, c) liberalized foreign exchange and trade, d) mature legal institutions.

\section{Variables and Hypotheses: Definition}

As previously stated, this paper investigated the variables that affect the degree to which subsidiaries located in transition economies are autonomous. Specifically, we decided to concentrate on Italian-owned SMEs located in CEECs.

The adopted Björkman's definition (2003) of subisdiary autonomy is consistent with Brooke's previous idea that autonomy characterizes an organization "in which units and sub-units possess the ability to take decisions for themselves on issues which are reserved to a higher level in comparable organizations" (1984: 9). On these bases, we assume that an autonomous subsidiary possesses some decision-making authority (O'Donnel 2000), even if it is limited to daily operations (Edwards/Ahmad/Moss 2002).

As previously mentioned, subsidiary autonomy can be investigated at two different levels: that of the subsidiary as a whole and that of a specific business function within the subsidiary. While we recognize that the level of autonomy may differ substantially between one specific business function (for instance, finance) and another (for instance, human resource management), we must also allow for the fact that our focus is on SMEs. In these organizations, and especially in the micro and small ones, functional responsibilities are often not clearly defined, and the subsidiary's general manager is typically authorized to decide on a significant set of decision areas. Moreover, Italian SMEs generally 
adopt a family-based governance system (the so-called "family capitalism") which tends to centralize all decisions on the founding entrepreneur (Mutinelli 2001, Colarossi et al. 2008). Taking our cue from Colarossi et al (2008), we conceptualized the subsidiary general manager's autonomy as our proxy for the degree of subsidiary autonomy.

As clearly shown by Björkman (2003), variations in subsidiary autonomy may be connected to parent company characteristics, subsidiary characteristics and environmental factors. Since our interest was to investigate subsidiaries located in transition economies, we decided to focus exclusively only on variables that are specifically related to the subsidiary (internal variables) and to the environment in which the subsidiary operates (external variable). We chose subsidiary size and the subsidiaries' local market strategic aims (market-seeking or cost reduction) as internal variables, and the degree of economic development in the host country as the external variable.

As shown in Table 1, subsidiary size has been assessed by several researchers for its impact on subsidiary autonomy. For instance, Hedlund (1981) found a curvilinear relationship between the two variables. Gates and Egelhoff (1986), and Young et al. (1985), found that the subsidiary enjoys a low level of autonomy at its foundation, subsequently gains autonomy up to a certain size, and thereafter declines. While Young et al. (1985) found a negative correlation between subsidiary size and subsidiary autonomy Gates and Egelhoff (1986) produced results that diverged on the basis of specific value chain activities. More specifically, they proposed a positive correlation with respect to manufacturing autonomy and a slightly negative one for marketing autonomy. Finally, Garnier (1982) found little support for any of the relationships thus far hypothesized.

Despite the absence of a definitive result, researchers generally recognize (see, inter alia, Young/Tavares 2004; Männik et al. 2005) that autonomy predominantly requires differing types of tangible and intangible resources. At the same time, the level of available resources is generally related to the firm's size. It follows that as a subsidiary develops - in terms of size - its resources will increase, which in turn will enlarge the subsidiary's autonomy (Johnston/Menguc 2007). We can therefore hypothesize that:

H1 The greater the subsidiary's size, the greater the number of subsidiaries, the more said subsidiaries will define themselves as autonomous.

The second variable we investigated is the subsidiary's local pursuit of its own strategic aim. Prompted by our previously reported literature review, we decided to assess whether market-seeking differed from cost reduction in their impact on subsidiary autonomy. It is widely recognized (see, inter alia, Mutinelli/Piscitello 1997) that at the beginning of the '90s Italian SMEs generally favoured the CEECs on the basis of the lower cost of labour. More recently, however, other 
countries - especially those in the Far East - have become increasingly attractive in this respect; it therefore seems that the aim of corporate Italy's presence in CEECs is rapidly changing. In this regard, some recent research (see, inter alia, Cotta Ramusino/Onetti 2006) proposed the idea of a "subsidiary's value chain" that will induce the progressive widening of the range of performed activities; said widening will, in turn, increase the subsidiary's degree of autonomy. This notion is consistent with the idea that the strategic aim pursued through FDI in CEECs - at least in the most developed of such countries (and notably in Poland) - seems to be primarily oriented to market enlargement (for a comprehensive analysis of the debate on this topic, see, inter alia, Reiljan et al. 2001). Assuming this notion to be valid, we need to understand how shifts in strategic objectives affect subsidiary autonomy.

Éltetö (1999) reported that market-seeking foreign investments generally coincide with weak headquarter-subsidiary relationships. In specular fashion, Petrochilos (1989) and Chudnovsky, Lopez and Porta (1997) concluded that efficiency-seeking foreign investments incontrovertibly require the close integration of local subsidiaries within the headquarters' internal network. We accordingly assume that:

H.2A Subsidiary autonomy increases when its aim is to seek new, local markets.

H.2B Subsidiary autonomy decreases when its aim is to reduce costs.

With regard to the relationship between subsidiary autonomy and the economic development of the host country, a necessary premise is that economic development is a continuously evolving process. That said, it is widely recognized (see, inter alia, Cantwell 1989; Andersson/Forsgren 1996; Narula 2003) that the local environment plays a fundamental role in the development of competences at the subsidiary level. On the basis of said competences, the local company will increase its autonomy from the parent company. Edwards et al. (2002) argue convincingly that the higher the economic development (in the sense of demand, the existence of potential sourcing partners and the degree of national innovation) of the subsidiary's host country, the greater the likelihood that the subsidiary will develop an extensive external network, improve its capacities, and consequently gain more autonomy.

However, a striking feature of the relevant literature is that most papers analyse subsidiaries located in advanced market economies; very little attention has been given to subsidiaries operating in emerging and transition economies. In one of the few studies that observe transition economies, Männik et al. (2005) revealed that subsidiaries in the relatively developed CEE countries, such as Slovenia and Hungary, scored higher on subsidiary autonomy than did their less developed fellow members of the CEE block. This finding was notably valid with respect to marketing, managerial and finance activities. In summary, we can assume that 
greater economic development in the host country can be considered a proxy for a local subsidiary's relatively superior resources and, consequently, for its relatively greater autonomy (Narula 2003). Accordingly, our third hypothesis is that:

H.3 Subsidiary autonomy increases when the host country's economic development is greater

\section{Data and methodology}

To test the stated hypotheses, we created an ex novo database of Italian firms that had invested CEECs. Data were severally sourced from the Italian Institute for Foreign Trade, from branches of the Italian and International Chambers of Commerce operating in the investigated CEECs, from Embassies and Consulates, and from several foreign and Italian entrepreneurial associations. We thus identified an initial database of 1,552 Italian firms that were believed to have invested in the CEECs. A subsequent check to exclude no longer active companies and investments reduced the database to 969 enterprises (as yet not differentiated by size) operating in 7 CEECs (Romania, Bulgaria, Poland, Slovak Republic, Hungary, Czech Republic, Slovenia). Further analysis revealed that 754 of the companies (78\% of the total number) were SMEs, as defined by the previously stated EU definition.

Conducted between 2005 and 2006, the survey developed a questionnaire and sent it by email to the previously identified companies. In the vast majority of cases, the survey was personally addressed to the local chief executive officer of the given firm.

Seventy-two medium, small and micro companies out of the previously identified companies replied exhaustively. We thus obtained an answer rate of about $9.55 \%$, quite similar to the average of the best international surveys (Harzing 1997). Considering the large number of questions in the questionnaire and their occasional complexity, this rate may be considered satisfactory. Table 2 summarizes the salient features of the responding companies. 
Table 2: Sample description

\begin{tabular}{|l|r|}
\hline Country & \% \\
\hline Poland & $37.50 \%$ \\
\hline Romanian & $19.44 \%$ \\
\hline Hungary & $15.28 \%$ \\
\hline Slovenia & $9.72 \%$ \\
\hline Czech Rep. & $9.72 \%$ \\
\hline Slovak Rep. & $6.94 \%$ \\
\hline Bulgarian & $1.39 \%$ \\
\hline
\end{tabular}

\begin{tabular}{|l|r|}
\hline Headquarter size (employes) & $\mathbf{\%}$ \\
\hline Micro & $29.17 \%$ \\
\hline Small & $31.94 \%$ \\
\hline Medium & $38.89 \%$ \\
\hline
\end{tabular}

\begin{tabular}{|l|r|}
\hline $\begin{array}{l}\text { Year of subsidiary } \\
\text { establishment }\end{array}$ & \% \\
\hline Before 1990 & $5.56 \%$ \\
\hline $1990-1994$ & $26.39 \%$ \\
\hline $1995-2000$ & $52.78 \%$ \\
\hline
\end{tabular}

\begin{tabular}{|l|r|}
\hline Industry & $\mathbf{\%}$ \\
\hline Manufacturing & $70.97 \%$ \\
\hline Others & $29.03 \%$ \\
\hline $2001-2005$ & $12.50 \%$ \\
\hline
\end{tabular}

Source: own calculations.

We then performed a quantitative analysis on the sample of 72 companies. In order to test the 3 hypotheses, we operationalised the adopted concepts as follows:

a. with regard to H.1, the number of employees was a proxy for subsidiary size;

b. with regard to H.2 A and B, respondents were asked to grade the respective importance to the FDI decision of the attractiveness of the local market (a proxy for market-seeking investments) and of the reduction of 
labour costs (a proxy for efficiency-seeking ) on a five-level Likert Scale (see below).

c. with regard to H.3, per capita GDP (current prices, US Dollars) was a proxy for the degree of the host country's economic development.

The five-level Likert scale identified the following values for subsidiary autonomy: 1 Scarce, 2 Barely significant, 3 Important, 4 Very important, 5 Highly important.

Finally, we performed a statistical analysis of the relationship between subsidiary autonomy, as indicated by the 72 identified subsidiaries, and the 3 stated variables. To this end, we used the Spearman's rank correlation coefficient (also known as Spearman's rho $(\rho)$ ), which we calculated by applying the Pearson correlation formula to the ranks of the data rather than to the actual data values themselves. Managed thus, many of the distortions that plague the Pearson correlation are reduced considerably. For the calculation of Spearman's rho, each set of data $X_{i}$ and $Y_{i}$ was converted to rankings $x_{i}$ and $y_{i}$ prior to calculation of the coefficient, where $X_{i}$ was the data that identified the level of subsidiary autonomy and $\mathrm{Y}_{\mathrm{i}}$ was, the data set collected for variables duly adapted to operationalize the proposed hypotheses.

\section{Results and Discussion}

As previously mentioned, the degree of autonomy indicated by the investigated subsidiaries was measured on a five-level Likert scale (1 Scarce, 2 Barely significant, 3 Important, 4 Very important, 5 Highly important). Figure 1 summarizes the results, which show huge diversification between companies. However, a widespread propensity for declaring autonomy is clearly evident in the percentage of companies replying "Highly important" and "Very important": $27.7 \%$. Addition of the "Important" value brings the autonomy value to a total of $52.7 \%$ against the $37.5 \%$ of respondents who classified their autonomy level as "Barely significant" or "Scarce". 
Figure 1: Strategic autonomy indicated by the subsidiary

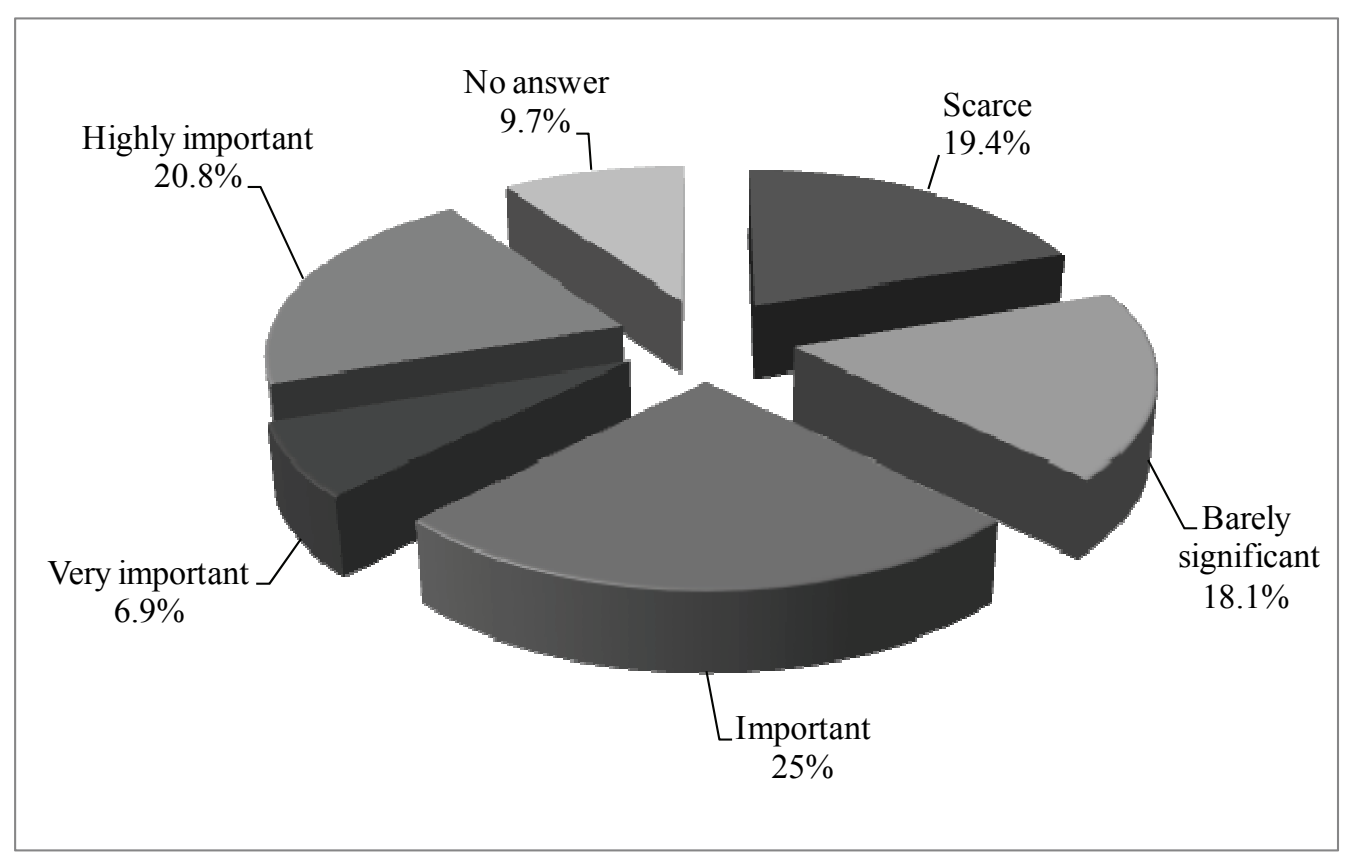

Source: own calculations.

Table 3 summarizes the Spearman's rank correlation coefficients that statistically measure the relationship between subsidiary autonomy and the variables chosen for the operationalization of hypotheses.

Table 3: Relationship between autonomy indicated by the subsidiary and hypothesis-operationalizing variables

\begin{tabular}{|l|l|l|}
\hline $\begin{array}{l}\text { Variables affecting subsidiary } \\
\text { autonomy }\end{array}$ & Spearman's p & P-value \\
\hline Subsidiary size & $-0.421^{* *}$ & 0.004 \\
\hline $\begin{array}{l}\text { Reasons for entering the } \\
\text { foreign market }\end{array}$ & & \\
\hline$-\quad$ Looking for new market & $0.521^{* *}$ & 0.000 \\
\hline$-\quad$ Reduction of labour costs & 0.004 & 0.978 \\
\hline Country development & 0.043 & 0.736 \\
\hline
\end{tabular}

Source: own calculations.

With respect to the first hypothesis, which regarded the relationship between subsidiary autonomy and its size in terms of number of employees, we unexpectedly found a negative correlation $(-0.412)$ that differed significantly from 0. Accordingly, H.1 is not confirmed. This is not entirely surprising, given the highly divergent findings identified in our literature review. Further instances are not lacking: while Alsegg (1971) found subsidiary autonomy to be 
positively correlated to its size, Youssef (1975) did not find any correlation, and Hedlund (1981) described a positive but weak correlation for micro-small firms and a negative correlation for large ones. Divergence also characterizes the more recent findings of Johnston and Menguc (2007), who analyzed a set of 313 Australian subsidiaries of mostly US, UK, European and Japanese MNCs. The authors found that while the subsidiary was relatively small, increasing subsidiary size would correlate with increasing resources in the subsidiary and, consequently, with an increase in subsidiary autonomy. This positive linear relationship persisted until an inflection point was reached, after which subsidiary autonomy began to decline, as a result of increasing coordination complexity. Moreover, the same authors suggest that there might be value in exploring a sinusoidal relationship between size and autonomy.

A possible explanation for the negative correlation between the two variables analyzed might subsist in the fact that the majority of the micro subsidiaries of our sample are characterized by a high level of autonomy. These micro subsidiaries were mainly established by micro or small Italian headquarters. The peak shown in the data collected for micro firms is, in our opinion, due to the lack of resources of the Italian headquarters. As previously mentioned, in most of the subsidiaries originating from micro Italian headquarters, the managing director was a family member of the founder's team (Mutinelli 2001; Colarossi et al. 2008). In this scenario, the subsidiary would benefit from the managing director's personal autonomy.

For the second hypothesis, which regarded the strategic aim (market- or cost efficiency-seeking) of the subsidiary, 25 out of the 72 respondents stated they were more interested (levels 4 and 5 on the five-level Likert scale) in local market penetration, while 22 contrastingly opted (levels 4 and 5 on the five-level Likert scale) for cost-efficiency. The remaining 5 companies indicated the joint aims of market- and efficiency-seeking. One interpretation of these findings is that the two strategies may be considered as interchangeable alternatives, a notion which was anticipated by Pearce (2009), who conceived the two strategies as plausibly sequential.

As already stated, we expected that the autonomy indicated by subsidiaries would be high for market-seeking companies (H.2A) and low for those seeking cost efficiency (H2.B). The results of Spearman's rho are extremely diversified; while the correlation regarding cost reduction aims does not differ significantly from 0 , that pertaining to market objectives is positive $(0.521)$, as expected, and differs significantly from 0 . As a consequence, H.2A is confirmed and H.2B is not.

For the third hypothesis, which regarded the economic development of the subsidiary's host country, and as already stated, we used per capita GDP (current prices, US Dollars) (source UNCTAD 2006) as a proxy for the level of 
development. We assumed that the higher the economic development of the host country, the greater the subsidiary's autonomy would be.

Unexpectedly, the statistical test did not reveal any evidence of correlation between subsidiary autonomy and the local country's economic development level. One possible reason for this reversal of expectation is the nonhomogeneity of the distribution of respondents between countries. We accordingly decided to focus exclusively on the top two countries in terms of number of respondents: Poland (25 subsidiaries) and Romania (14 subsidiaries). Two caveats to this approach are in order. Firstly, the two countries in question differed substantially in terms of per capita GDP (current prices, US Dollars). In 2006 (the year in which data were collected), the per capita GDP (current prices, US Dollars) of Poland was \$ 8,962.89 while for Romania it was $\$ 5,686.88$, i.e., more than 3,000 dollars per capita less than Poland's. Secondly, less direct confirmation of the difference between the two countries comes from the dates of their respective entrances to the European Union (EU): Poland entered in 2004, Romania in January 2007. Analysis of our data also revealed that while Italian SMEs commenced FDI in Poland in 1989, they only entered Romania in 1996. This findings appear also consisting with the trend of all FDI in the two countries (Annex 1). At the very least, this evidence demonstrates a difference in the respective attractiveness of the two countries under investigation, which in turn implies differences in their levels of economic development. In Annex 3 the most relevant economic indicators of the two countries are summarized.

The statistical test, as exclusively focused on data related to Poland and Romania, shows a positive and statistically significant correlation $\left(\rho=0.451^{* *}\right.$; P-value 0.004) between subsidiary autonomy and the level of the host country's economic development. As a consequence, H.3 is partially confirmed, conditionally upon restriction of analysis to the 2 most highly represented countries in the sample.

It should be noted that despite having in common high rates of response to the survey, Italian SME subsidiaries in Poland and Romania differ on various accounts. Subsidiaries in Poland were 59\% market-seeking, while only $27 \%$ of subsidiaries in Romania were similarly motivated. The converse percentages are similarly unequivocal: only $30 \%$ of subsidiaries in Poland were oriented to costeffectiveness, against the $50 \%$ thus oriented in Romania. Furthermore, after 1999 no Italian SMEs entered the Polish market with cost-efficiency objectives, while they continued to pursue cost-efficiencies in Romania at least until 2006 (the endpoint for this survey's data collection). 
Table 4: Summary of Results

\begin{tabular}{|c|c|c|c|}
\hline $\begin{array}{l}\text { Variables affecting } \\
\text { subsidiaries } \\
\text { autonomy }\end{array}$ & Theory & $\begin{array}{l}\text { Statistical test } \\
\text { results }\end{array}$ & $\begin{array}{l}\text { Hypothesis } \\
\text { verified? }\end{array}$ \\
\hline Subsidiary size & $\begin{array}{l}\text { Positive correlation (Alsegg } \\
\text { 1971; Neganghi/Baliga 1981; } \\
\text { Welge 1981; Harzing 1999; } \\
\text { Gates/Egelhoff 1986); } \\
\text { Positive but weak (Garnier } \\
\text { 1982) and only for fairly } \\
\text { small firms (Hedlund 1981); } \\
\text { Positive albeit not statistically } \\
\text { significant for size in terms of } \\
\text { employment, negative and } \\
\text { significant for size in terms of } \\
\text { sales (Taggart/Hood 1999) } \\
\text { Negative } \\
\text { (Young/Hood/Hamill 1985; } \\
\text { Picard 1978; Khandwalla } \\
\text { 1973); } \\
\text { Negative for large companies } \\
\text { (Hedlund 1981); } \\
\text { No correlation (Youssef } \\
\text { 1975); } \\
\text { An inverted U-shaped } \\
\text { relationship } \\
\text { (Johnston/Menguc 2007) }\end{array}$ & $\begin{array}{l}\text { Negative correlation } \\
(-0.412) \text { and P-value } \\
0.004 \text { : correlation } \\
\text { significantly } \\
\text { different from } 0\end{array}$ & $\begin{array}{l}\text { No, but data show } \\
\text { some evidence } \\
\text { for large } \\
\text { subsidiaries }\end{array}$ \\
\hline \multicolumn{4}{|l|}{$\begin{array}{l}\text { Reasons for entering } \\
\text { the foreign market: }\end{array}$} \\
\hline $\begin{array}{l}- \text { Pursuit of new } \\
\text { markets }\end{array}$ & $\begin{array}{l}\text { weak positive correlation } \\
\text { (Éltetö 1999) } \\
\text { subsidiary's autonomy is a } \\
\text { prerequisite (Petrochilos } \\
\text { 1989; } \\
\text { Chudnovsky/Lopez/Porta } \\
\text { 1997) }\end{array}$ & $\begin{array}{l}\text { Positive correlation } \\
\left(0.521^{* *}\right) \text { and } \mathrm{P}- \\
\text { value } 0.000 \text { : } \\
\text { correlation } \\
\text { significantly } \\
\text { different from } 0\end{array}$ & Yes \\
\hline $\begin{array}{l}-\quad \text { Reduction of } \\
\text { labour costs }\end{array}$ & & $\begin{array}{l}\text { Correlation not } \\
\text { significantly } \\
\text { different from } 0\end{array}$ & No \\
\hline
\end{tabular}




\begin{tabular}{|l|l|l|l|}
\hline $\begin{array}{l}\text { Country } \\
\text { development }\end{array}$ & $\begin{array}{l}\text { Correlation not clearly } \\
\text { definite (Hedlund 1981); } \\
\text { Positive correlation } \\
\text { (Männik/Varblane/Hannula } \\
\text { 2005; Edwards/Ahmad/Moss } \\
\text { 2002) }\end{array}$ & $\begin{array}{l}\text { Correlation not } \\
\text { significantly } \\
\text { different from 0 }\end{array}$ & $\begin{array}{l}\text { No, but data show } \\
\text { some evidence } \\
\text { for Romania and } \\
\text { Poland } \\
\text { (positive } \\
\text { correlation } \\
0.451^{* *} \text { and P- } \\
\text { value 0.004) }\end{array}$ \\
\hline
\end{tabular}

\section{Conclusions}

This paper aims to contribute to research on the headquarter-subsidiary relationship by analyzing variables influencing subsidiaries' autonomy. The analysis involved a sample of 72 CEEC-located subsidiaries of micro, small and medium-sized Italian companies.

Our data show that $52.7 \%$ of respondents are characterized by a level of subsidiary autonomy that ranged from "highly important" to "important". Of the three proposed research hypothesis, two proved not to be incompletely confirmed, although the data do show contrasting evidence. In contrast, a clear positive correlation was found between subsidiary autonomy and the strategic aims underlying the FDI decision, at least as regards the aim of local market exploitation. This result appears to be additionally and intimately connected with the geographical distribution of the companies investigated. Although the respondents of our survey were, unfortunately, not evenly balanced across each of the individual host countries (Poland is over-represented and Bulgaria underrepresented), our data show clear findings for at least Polish and Romanian subsidiaries. In this regard, it is noteworthy that 59\% of Polish subsidiaries pursued market-seeking aims, while $68 \%$ of Romanian subsidiaries costreduction aims. Furthermore, $78 \%$ of Polish subsidiaries stated they enjoyed a more than substantial strategic autonomy, while only $42 \%$ of their Romanian equivalents concurred. These results accrue far greater weight if account is taken of these two countries' highly differing levels of economic development (Poland's per capita GDP is $57.6 \%$ higher than Romania's). This finding confirms Lankes and Venables (1996) assertion that subsidiaries' strategic aims vary on the basis of their host countries' level of economic development. It seems to follow that variables regarding the subsidiary are closely interconnected with those regarding the host country, which in turn confirms Björkman's assumption (2003) that both components directly affect variations in subsidiary autonomy. This finding could prove to be quite important because it clearly confirms that subsidiary autonomy is a complex construct that does not depend exclusively on the country of origin. This is consistent with Männik, Varblane and Hannula $(2005 ; 2006)$ findings on the degree of autonomy characterizing specific subsidiaries' business functions. From their analysis of a 
sample of 433 companies operating in five CEECs, they concluded that subsidiary autonomy levels are extremely heterogeneous, and can only be explained with a multidimensional model that takes country-, industry-, and firm-level factors into account.

Despite the uniqueness of the database we created for our analysis, we recognise that our investigation is limited by the uneven distribution of the respondents in our survey between the Eastern European countries considered. Said limit constrains us to be cautious in generalizing the findings derived from our analysis. However, it seems appropriate to use some of the main findings to define further analysis.

Specifically, further research could usefully focus on the relationship between the level of subsidiary autonomy and the so-called "subsidiary value chain" development (Cotta Ramusino/Onetti 2006), i.e., the progressive widening of the range of activities performed. This focus would also be consistent with Young and Tavares' suggestion (2004) to shift from a coarse-grained to a more fine-grained perspective on autonomy. In such a shift, autonomy should be defined in relation both to specific value adding activities and to the distinction between strategic and operational decisions within value adding activities. Moreover, and as proposed by Birkinshaw (2000), a greater variety of subsidiary roles should be taken into account, even if it is not certain - at least to date - that micro and small Italian companies would concede specific mandates to their CEE subsidiaries.

The most relevant implication of our findings is addressed to CEECs policy makers. As Majcen, Radosevic and Rojec (2009) pointed out, FDIs are an important vehicle for narrowing the productivity gap between CEECs and Western European countries. Our research shows that foreign subsidiaries localized in the former countries are the main profit generators and invest more in R\&D than domestic firms (Meyer 1998; Holland et al. 2000; Hunya 2000; Resmini 2000; Rojec 2000; Konings 2001; Damijan et al. 2003; Majcen et al., 2009). However, as clearly synthesized by Holland et al., FDI inflows in CEECs improve "the overall growth potential of the recipient economies, but primarily through productivity improvements within the foreign affiliates themselves, rather than through increased capital investment, or technology spillovers to domestic firms" (2000: 169). At the same time, Jindra, Giroud and Scott-Kennel (2009) put in evidence that the developmental impact of foreign subsidiaries via vertical linkages is highest when these firms demonstrate to have enhanced autonomy. As a consequence CEECs policymakers should focus their policies aimed at attracting FDIs targeting foreign companies having local market exploitation goals, rather than firms just looking for cost reduction. This is consistent also with recent findings regarding the so-called "back-shoring" phenomenon (see, among others, Kinkel/Maloca 2009; Leibl et al 2011; Kinkel 
2012), that is the process by which previously off-shored production are moved back to the domestic location.

With respect to HQ managers, the main implication is related to the need of assuming a multivariate while defining the level of autonomy of their foreign subsidiaries. However, they must take into proper account that the overall strategic aims significantly impact on the required level of subsidiary autonomy.

For the subsidiary managers - expecially for those having assigned by the HQ more production related objectives - it becomes extremely important to promote a subsidiary development life cycle based on the continous enlargement of the subsidiary value chain (Cotta Ramusino/Onetti 2006).

\section{References}

Alsegg, R.A. (1971): Control Relationships between U.S. Corporations and their European Subsidiaries. AMA Research Study 107.

Ambos, T.C./Birkinshaw, J. (2010): Headquarters' Attention, Strategic Choice and Performance in MNC Subsidiaries, in: Management International Review, 50, 4, 449469.

Anderson, U./Forsgren, M. (1996): Subsidiary embeddedness and control in the multinational corporation, in: International Business Review, 5, 5, 487-508.

Banca d'Italia (2006): Indagine sulle imprese industriali e dei servizi. Supplementi al bollettino statistico, n. 41.

Barrell, R./Pain, N. (1999): Trade Restraints and Japanese Direct Investment Flows, in: European Economic Review, 43, 29-45.

Bartlett, C.A./Goshal, S. (1986): Tap Your Subsidiaries for Global Reach, in: Harvard Business Review, 64, 6, 87-94.

Bartlett, C.A./Ghoshal, S. (1989): Managing Across Borders. Boston, MA: Harvard School Press.

Bartlett, C.A./Doz, Y./Hedlund, G. (Eds.) (1990): Managing the Global Firm. London and New York: Routledge.

Bevan, A.A./Estrin, S./Meyer, K. (2004): Foreign investment location and institutional development in transition economies, in: International Business Review, 13, 43-64.

Birkinshaw, J. (2000): Entrepreneurship in the Global Firm. London: Sage Publications.

Birkinshaw, J./Hood, N. (1997): An Empirical Study of Development Processes in Foreignowned Subsidiaries in Canada and Scotland, in: Management International Review, 37, 4, 339-364.

Birkinshaw, J.M./Hood, N. (1998): Multinational Corporate Evolution and Subsidiary Development. London: Macmillan.

Birkinshaw, J.M./Lingblad M. (2005): Intra-firm competition and charter evolution in the multi-business firm, in: Organization Science, 16, 6, 674-786. 
Birkinshaw, J.M./Morrison, A.J. (1995): Configurations of Strategy and Structure in Subsidiaries of Multinational Corporations, in: Journal of International Business Studies, 26, 4, 729-754.

Björkman, A. (2003): Subsidiary power and autonomy. Paper presented at 29th Annual EIBA Conference, Copenhagen, December 11-13.

Borsos-Torstila, J. (1998): Determinants of Foreign Direct Investment Operations of Finnish Multinational Companies in Transition Economies in 1990-1995. Helsinki.

Brooke, M.Z. (1984): Centralization and Autonomy. A Study in Organization Behaviour. London and New York: Holt, Rinehart and Winston.

Cantwell, J.A. (1989): Technological Innovation and Multinational Corporations, Oxford: Basil Blackwell.

Chen S. (2011): New Challenges for International Business Research: Back to the Future, in: Multinational Business Review, 19, 1, 94-97.

Chudnovsky, D./Lopez A./Porta F. (1997): Market or Policy Driven? The Foreign Direct Investment Boom in Argentina, in: Oxford Development Studies, 25, 2, 173-188 (cited by http://www.ebscohost.com pp. 1-16).

Colarossi F./Giorgino M./Steri R./Viviani D. (2008): A Corporate Governance Study on Italian Family Firms, in: Corporate Ownership \& Control, 5, 4, 93-103.

Cotta Ramusino, E./Onetti, A. (2006): L'internazionalizzazione delle imprese italiane nell'Est Europeo. Evidenze e Prospettive, in: Sinergie-Rapporti di ricerca, 24.

D’Cruz, J.R. (1986): Strategic Management of Subsidiaries, in: Etemad, H., \& Dulude, L.S. (Eds.), Managing the Multinational Subsidiary. Response to Environmental Changes and to Host Nation R\&D Policies, London: Croom Helm.

Damijan, J. P./Majcen, B./Rojec, M./Knell M. (2003): The role of FDI, R\&D accumulation and trade in transferring technology to transition countries: evidence from firm panel data for eight transition countries, in: Economic Systems, 27, 2, 189-204.

De Bodinat, H. (1975): Influence in the Multinational Corporation: The Case of Manufacturing. Doctoral Dissertation, Boston: Harvard University, School of Business.

Doz, Y. (1986): Strategic Management in Multinational Companies. Oxford: Pergamon Press.

Edwards R./Ahmad A./Moss S. (2002): Subsidiary autonomy, in: Journal of International Business Studies, 33: 183-192.

Éltetö, A. (1999): The Impact of the Foreign Trade of Central European Countries. Paper presented at the Workshop "Impact of Foreign Direct Investment on the International Competitiveness of CEEC Manufacturing and EU Enlargement", Budapest 19-20 November.

Forsgren, M. (1989): The Internationalization Process of Swedish Firms. London: Routledge.

Forsgren, M. (1990): Managing the International Multi-Centre Firm: Case Studies from Sweden, in: European Management Journal, 2.

Forsgren, M./Johanson, J. (Eds.) (1992): Managing Networks in International Business. Philadelphia: Gordon and Breach. 
Forsgren, M./Pedersen, T. (1998): Centers of Excellence in Multinational Companies: The case of Denmark, in: Birkinshaw, J., \& Hood, N. (Eds.), Multinational Corporate Evolution and Subsidiary Development, London: Macmillan.

Forsgren, M./Holm, U./Johanson, J. (1991): Internationalisering av andra graden, in: R. Andersson, E. Ekstedt, \& A. Malmberg (Eds.), Internationalisering, företagen och samhället. SNS.

Forsgren, M./Holm, U./Johanson, J. (1992): Internationalization of the Second Degree: The Emergence of European Based Centers in Swedish Firms, in: Young S., Hamill J., (Ed.) Europe and the multinationals, London: Edward Elgar.

Forsgren, M./Holm, U./Johanson, J. (1995): Division Headquarters go Abroad - A Step in the Internationalization of the Multinational Corporation, in: Journal of Management Studies, 32, 4, 457-491.

Gammelgaard J./McDonald F./Stephan A./Tüselmann H./Dörrenbächer C. (2012): The impact of increases in subsidiary autonomy and network relationships on performance. International Business Review, available online 15 February 2012.

Garibaldi, P./Mora, N./Sahay, R./Zettelmeyer, J. (1999): What Moves Capital to Transition Economies? Materials of the IMF Conference "A Decade of Transition: Achievements and Challenges", 49.

Garnier, G./Osborn, T.N./Galicia, F./ Lecon, R. (1979): Autonomy in the Mexican affiliates of US multinational corporations, in: Columbia Journal of World Business, 14, 1, 7890 .

Garnier, G.H. (1982): Context and Decision Making Autonomy in the Foreign Affiliates of U.S. Multinationals Corporations, in: Academy of Management Journal, 25, 4, 893908.

Gates, S.R./Egelhoff, W.G. (1986): Centralization in Headquarter-Subsidiary Relationships, in: Journal of International Business Studies, 17, 2, 71-92.

Ghoshal, S./Bartlett, C.A. (1991): The Multinational Corporation as an Interorganizational Network, in: Academy of Management Review, 15, 4.

Ghoshal, S./Nohria, N. (1989): Internal Differentiation Within the Multinational Corporation, in: Strategic Management Journal, 10.

Guimaraes, P./Rolfe, R.J./Doupnik, T./Woodward, D.P. (1997). The Locational Determinants of Foreign Direct Investment in Central Europe, Working Paper D- 97-02, Center for International Business Education and Research (CIBER), Moore - University of South Carolina.

Gupta, A.K./Govindarajan, V. (1991): Knowledge Flows and the Structure of Control Within Multinational Corporations, in: Academy of Management Review, 16, 4, 768-792.

Harzing, A.-W.K. (1997): Response Rates in International Mail Surveys: Results of 22 Countries Study, in: International Business Review, 6, 6, 641-665.

Harzing, A-W.K. (1999): Managing the multinationals: an international study of control mechanism. Northampton: Edward Elgar. 
Hedlund, G. (1977): Organization as a Matter of Style, in: Mattson, L.G., \& WiedersheimPaul, F. (1979) (Eds.), Recent Research on the Internationalization of Business. Uppsala: Acta Universitatis Upsaliensis Symposia Universitatis Upsaliensis Annum Quingentesimus Celebrantis, No. 13.

Hedlund, G. (1981): Autonomy of Subsidiaries and Formalization of Headquarter-Subsidiary relationships in Swedish MNCs, in: Otterbeck, L. (1981) (Ed.), The Management of Headquarter-Subsidiary Relationships in Multinational Corporations, Aldershot: Gower.

Hedlund, G. (1986): The hypermodern MNC-a heterarchy?, in: Human Resource Management, 25, 1, 9-25.

Holland, D./Pain, N. (1998a): The Determinants and Impact of Foreign Direct Investment in the Transition Economies: A Panel Data Analysis. Materials of the conference "Convergence or Divergence", Buckinghamshire, pp. 300-325.

Holland, D./Pain, N. (1998b): The Diffusion of Innovations in Central and Eastern Europe: A Study of the Determinants and Impact of Foreign Direct Investment. Materials of the conference "Convergence or Divergence: Aspirations and Reality in Central and Eastern Europe and Russia", Buckinghamshire, 49.

Holland, D./Sass, M./Benaček, V./Gronicki, M. (2000): The determinants and impact of FDI in Central and Eastern Europe: a comparison of survey and econometric evidence, in: Transnational Corporations, 9, 3, 163-213.

Holm, U./Pedersen, T. (2000): The emergence and impact of MNC centers of excellence: a subsidiary perspective. London: McMillan Press.

Holm, U./Johanson, J./Thilenius, P. (1993): Headquarter Knowledge of Subsidiary Network Contexts in the Multinational Corporation, in: International Studies of Management and Organization, 25, 1-2, 97-120.

Hood, N./Taggart, J.H. (1999): Subsidiary development in German and Japanese manufacturing subsidiaries in the British Isles, in: Regional Studies, 33, 6, 513-528.

Hunya, G. (2000): Foreign penetration in central European manufacturing. In Hunya G. (Ed.), Integration through Foreign Direct Investment: Making Central Europe Competitive, Cheltenham: Edward Elgar.

ICE (2009): Italia Multinazionale 2009. Roma: Istituto per il Commercio Estero.

IMF (2006): World Economic Outlook 2006. Washington: International Monetary Fund.

Jarillo, J.C./Martinez, J.L. (1990): Different Roles for Subsidiaries: The case of Multinational Corporation in Spain, in: Strategic Management Journal, 11, 7, 501-512.

Jindra, B./Giroud, A./Scott-Kennel, J. (2009): Subsidiary Roles, Vertical Linkages and Economic Development: Lessons from Transition Economies, in: Special issue of the Journal of World Business, 44, 2.

Johnston, S./Menguc, B. (2007): Subsidiary Size and the Level of Subsidiary Autonomy in Multinational Corporations: A Quadratic Model Investigation of Australian Subisidiaries, in: Journal of International Business Studies, 38, 5, 787-801.

Khandwalla, P.N. (1973): Uncertainty and the Optimal Design of Organizations, Working Paper, McGill University, Toronto. 
Kinkel, S. (2012): Trends in Production Relocation and Backshoring Activities: Changing Patterns in the Course of the Global Economic Crisis, in: International Journal of Operations \& Production Management, 32, 6, 696-720.

Kinkel, S./Maloca, S. (2009): Drivers and antecedents of manufacturing off-shoring and backshoring - A German perspective, in: Journal of Purchasing \& Supply Management, 15, 154-165.

Kobrin, S. J. (1991): An empirical analysis of the determinants of global integration, in: Strategic Management Journal, 12, 17-32.

Konings, J. (2001): The effects of FDI on domestic firms. Economics of Transition, 9(5): 61933.

Lankes, H.-P./Stern, N. (1998): Capital Flows to Eastern Europe and the Former Soviet Union. EBRD Working Paper, 27(31).

Lankes, H.-P./Venables, A.J. (1996): Foreign Direct Investment in Economic Transition: The Changing Pattern of Investments, in: Economies of Transition, 4, 2, 331-347.

Leibl, P./Morefield, R./Pfeiffer, R. (2011): A study of effects of backshoring in the EU, in: Journal of Business and Behavioural Sciences, 23, 2, 72-79.

Lindgren, U. (1982): Foreign Acquisitions, Management of Integration Processes. Stockholm: IIB/EFI Stockholm School of Economics.

Majcen, B./Radosevic, S./Rojec, M. (2009): Nature and determinants of productivity growth of foreign subsidiaries in Central and East European Countries, in: Economic Systems, $33,2,127-137$.

Majocchi, A./ Onetti A. (2002): Le Pmi Italiane in Romania. I risultati di una ricerca sulle strategie delle imprese italiane nei distretti industriali romeni, in Velo, D./Majocchi A. (eds.): L'internazionalizzazione delle piccole e medie imprese nell'Europa Centro Orientale, Milano: Giuffrè Editore, 79-142.

Majocchi, A./Strange, R. (2006): Economic Liberalisation and the FDI Location Decision: Evidence from Italian firms in Central and Eastern Europe, in: Journal of East-West Business, 13, 2/3, 93-114.

Makhija, M./Kim, K./Williamson S. (1997): Measuring globalization of industries using a national approach: Empirical evidence across five countries and over time, in: Journal of International Business Studies, 4, 28, 679-712.

Männik, K./Hannula, H./Varblane, U. (2006): Foreign Subsidiary Autonomy and Performance in Five Central and East European Countries, in: Hannula., H.S., Radoševic \& von Tunzelmann, N. Estonia, The New EU Economy, Ashgate Publishing.

Männik, K./Varblane, U./Hannula, H. (2005): The Role of Country, Industry and Firm Specific Effects on the Autonomy of a Multinational Corporation's Subsidiary in Central and East European Countries., in: East-West Journal of Economics and Business, 8, 1-2, 101-133.

Manolopoulos D. (2006): The Concept of Autonomy in the Subsidiary Management Research: A Conceptual Investigation, in: Journal of Transnational Management, 11, 4. 
Marinov, M./Marinova, S. (1999): Foreign Direct Investment Motives and Marketing Strategies in Central and Eastern Europe, in: Journal of East-West Business, 5, 1-2, $25-55$.

Martínez, K./Jarillo, J.C. (1991): Coordination demands of international strategies, in: Journal of International Business Studies, 22, 3, 429-44.

McDonald F./Warhurst S./Allen M. (2008): Autonomy, Embeddedness, and the Performance of Foreign Owned Subsidiaries, in: Multinational Business Review, 16, 3, 73-92.

Meyer, K. (1995): Direct Foreign Investment in Eastern Europe: The Role of Labor Costs, in: Comparative Economic Studies, 37,4, 69-88 (cited by http://www.ebscohost.com pp. 1-16).

Meyer, K. (1998): Direct Investment in Economies in Transition: Making Central European Industries Competitive, Cheltenham: Edward Elgar.

Mirchandani, D./Lederer, A. (2004): IS Planning Autonomy in U.S. Subsidiaries of Multinational Firms, in: Information \& Management, 4, 1021-036.

Mutinelli, M. (2001): L'internazionalizzazione produttiva delle imprese italiane: caratteristiche strutturali, tendenze evolutive e motivazioni, in: Garavello O., \& Barba Navaretti, G. (Eds.), Investimenti esteri delle imprese italiane nei paesi emergenti, Milano: Giuffrè Editore.

Mutinelli, M./Piscitello, L. (1997): La scelta della struttura prioritaria nell'internazionalizzazione dell'industria italiana: il ruolo della dimensione e dell'esperienza, in: Economia e Politica Industriale, 94, 1.

Mutinelli, M./Piscitello, L. (1998): The Influence of Firm's Size and International Experience on the Ownership Structure of Italian FDI in Manufacturing, in: Small Business Economics, 11, 1, 43-56.

Narula, R. (2003): Understanding absorptive capacities in an "innovation systems" context: consequences for economic and employment growth. First draft, prepared for the Internal Labour Organisation, Geneva.

Neghandi, A.R./Baliga, B.R. (1981): Internal Functioning of American, German and Japanese Multinational Corporations, in: Otterbeck, L., (Ed.), The Management of HeadquarterSubsidiary Relations in Multinational Corporations, Aldershot: Gower.

Nohria, N./Gulati, R./Ghoshal, S. (1994): The N-Form: Re-conceptualizing Structure and Innovation in Multinational Corporations. Working Paper Harvard University, Northwestern University and INSEAD.

O'Donnel, S.W. (2000): Managing foreign subsidiaries: agents of headquarters, or an interdependent network?, in: Strategic Management Journal, 21, 525-48.

Otterbeck, L. (Ed.) (1981): The Management of Headquarter-Subsidiary Relationships in Multinational Corporations. Aldershot: Gower.

Pearce R. (2009). Multinationals' Strategies and the Economic Development of Small Economies: A Tale of Two Transitions, in: Management International Review, 49, 8194

Petrochilos, G.A. (1989): Foreign Direct Investment and the Development Process. Sydney: Avebury. 
Picard, J. (1978): Factors of Variance in Multinational Marketing Control, in: Mattson, L.G., \& Wiedersheim-Paul, F. (1979), (Eds.), Recent Research on the Internationalization of Business. Uppsala: Acta Universitatis Upsaliensis Symposia Universitatis Upsaliensis Annum Quingentesimus Celebrantis, No. 13.

Picard, J. (1980): Organization Structures and Integrative Devices in European Multinational Corporations, in: Columbia Journal of World Business, 4, 9-18.

Pye, R.B.K. (1997): Foreign Direct Investment in Central Europe (the Czech Republic, Hungary, Poland, Romania, and Slovakia): Results from a Survey of Major Western Investors. CUBS Finance Working Paper, April, 61.

Reiljan, J. E. (1999): Otseste välisinvesteeringute liikumist mõjutavad sihtriigi makrotegurid, 140.

Reiljan, J., Reiljan, E., \& Andresson, K. (2001). Attractiveness of Central and Eastern European Countries for Foreign Investment in the Context of European Integration: The Case of Estonia, 41st ERSA Congress, Zagreb, 29th August -1th September.

Resmini, L. (2000): The Determinants of Foreign Direct Investment into the CEECs: New Evidence from Sectoral Patterns, in: The Economics of Transition, 8, 3, 665-689.

Rojec, M. (2000): Restructuring and efficiency upgrading with FDI. In Hunya G. (Ed.), Integration through Foreign Direct Investment: Making Central European Industries Competitive, Cheltenham: Edward Elgar.

Roth, K./Morrison, A. (1992): Implementing global strategy: Characteristics of global subsidiary mandates, in: Journal of International Business Studies, 23, 715-736.

Singh, R.K.D.N. (1981): Policy Issues and Trends in Parent-Affiliate Relationships in Developing Countries. In Otterbeck, L., The Headquarters-Subsidiary Relationship in Multinational Corporations. Aldershot: Gower.

Slangen A. H. L./Hennart J. F. (2008): Do Foreign Greenfields Outperform Foreign Acquisitions or Vice Versa? An Institutional Perspective, in: Journal of Management Studies, 45, 7, 1301-1328.

Snow, C.C./Miles, R.E./Coleman, J.-Jr. (1992): Managing $21^{\text {st }}$ Century Network Organizations, in: Organizational Dynamics, 20, 3, 5-19.

Taggart, J. (1997): Autonomy and Procedural Justice: A Framework for Evaluating Subsidiary Strategy, in: Journal of International Business Studies, 28, 1, 51-77.

Vachani, S. (1999): Global Diversification's Effect on Multinational Subsidiaries' Autonomy, in: International Business Review, 8, 5, 535-560.

Van den Bulcke, D./Halsberghe, E. (1984): Employment decision-making in multinational enterprises: survey results from Belgium. International Labour Office Geneva.

Wang, Z.Q./Swain, N.J. (1995): The Determinants of Foreign Direct Investment in Transforming Economies: Empirical Evidence from Hungary and China. Weltwirtschaftlisches Archiv, Band 131: 359-382.

Welge, M. (1981): The Effective Design of Headquarter-Subsidiary Relationships in German MNCs, in Otterbeck, L., The Headquarters-Subsidiary Relationship in Multinational Corporations. Aldershot: Gower.

White, R.E./Poynter, T.A. (1984): Strategies for Foreign-Owned Subsidiaries in Canada, in: Business Quarterly, 49, 2. 
Young, S./Tavares, A. (2004): Centralization and Autonomy: Back to the Future, in: International Business Review, 13, 2, 215-237.

Young, S./Hood, N./Hamill, J. (1985): Decision-Making in Foreign owned Multinational Subsidiaries in the United Kingdom. International Labour Office (Geneva). Multinational Enterprises Programme Working Paper 35.

Youssef, S.M. (1975): Contextual Factors Influencing Control Strategy of Multinational Corporations, in: Academy of Management Journal, 18, 1, 136-143.

Ziacik, T. (2000): An Assessment of the Estonian Investment Climate: Results of a Survey of Foreign Investors and Policy Implications. BOFIT Discussion Papers, 3(52). 
Subsidiary autonomy in transition economies: Italian SMEs in CEE countries

Annex 1 FDI Inflow in the CEECs (Millions US\$ at current prices and current exchange rate)

\begin{tabular}{|c|c|c|c|c|c|c|}
\hline Year & $\begin{array}{l}\text { Czech } \\
\text { Republic }\end{array}$ & Hungary & Poland & Romania & Slovakia & Slovenia \\
\hline 1989 & & & $\$ 11,00$ & & & \\
\hline 1990 & & $\$ 553,81$ & $\$ 88,00$ & $\$ 0,01$ & & \\
\hline 1991 & & $\$ 1.470,42$ & $\$ 359,00$ & $\$ 40,00$ & & \\
\hline 1992 & & $\$ 1.477,00$ & $\$ 678,00$ & $\$ 77,00$ & & $\$ 111,00$ \\
\hline 1993 & $\$ 653,47$ & $\$ 2.442,95$ & $\$ 1.715,00$ & $\$ 94,00$ & $\$ 179,14$ & $\$ 112,60$ \\
\hline 1994 & $\$ 868,31$ & $\$ 1.143,37$ & $\$ 1.875,00$ & $\$ 341,00$ & $\$ 255,17$ & $\$ 116,27$ \\
\hline 1995 & $\$ 2.561,83$ & $\$ 5.103,49$ & $\$ 3.659,00$ & $\$ 419,00$ & $\$ 2.587,15$ & $\$ 151,67$ \\
\hline 1996 & $\$ 1.428,44$ & $\$ 3.299,58$ & $\$ 4.498,00$ & $\$ 263,00$ & $\$ 369,74$ & $\$ 173,06$ \\
\hline 1997 & $\$ 1.301,37$ & $\$ 4.167,32$ & $\$ 4.908,00$ & $\$ 1.215,00$ & $\$ 230,60$ & $\$ 333,15$ \\
\hline 1998 & $\$ 3.716,36$ & $\$ 3.334,86$ & $\$ 6.398,40$ & $\$ 2.031,00$ & $\$ 706,83$ & $\$ 217,84$ \\
\hline 1999 & $\$ 6.329,67$ & $\$ 3.311,94$ & $\$ 7.270,78$ & $\$ 1.027,03$ & $\$ 428,50$ & $\$ 105,67$ \\
\hline 2000 & $\$ 4.985,21$ & $\$ 2.764,06$ & $\$ 9.445,31$ & $\$ 1.056,75$ & $\$ 1.932,28$ & $\$ 137,28$ \\
\hline 2001 & $\$ 5.641,74$ & $\$ 3.936,05$ & $\$ 5.701,17$ & $\$ 1.157,93$ & $\$ 1.583,81$ & $\$ 368,97$ \\
\hline 2002 & $\$ 8.482,05$ & $\$ 2.993,57$ & $\$ 4.122,76$ & $\$ 1.140,65$ & $\$ 4.141,86$ & $\$ 1.621,22$ \\
\hline 2003 & $\$ 2.102,74$ & $\$ 2.137,40$ & $\$ 4.587,72$ & $\$ 2.196,30$ & $\$ 2.159,97$ & $\$ 305,23$ \\
\hline 2004 & $\$ 4.974,50$ & $\$ 4.265,73$ & $\$ 12.874,42$ & $\$ 6.435,59$ & $\$ 3.030,46$ & $\$ 825,91$ \\
\hline 2005 & $\$ 11.653,25$ & $\$ 7.708,96$ & $\$ 10.293,37$ & $\$ 6.482,86$ & $\$ 2.428,59$ & $\$ 587,57$ \\
\hline 2006 & $\$ 5.462,63$ & $\$ 6.817,54$ & $\$ 19.603,24$ & $\$ 11.366,87$ & $\$ 4.692,66$ & $\$ 643,93$ \\
\hline 2007 & $\$ 10.443,82$ & $\$ 3.950,84$ & $\$ 23.560,76$ & $\$ 9.921,47$ & $\$ 3.580,76$ & $\$ 1.514,29$ \\
\hline 2008 & $\$ 6.451,00$ & $\$ 6.325,44$ & $\$ 14.838,70$ & $\$ 13.908,52$ & $\$ 4.686,82$ & $\$ 1.947,49$ \\
\hline 2009 & $\$ 2.926,81$ & $\$ 2.048,43$ & $\$ 12.932,11$ & $\$ 4.844,11$ & $-\$ 6,08$ & $-\$ 652,50$ \\
\hline 2010 & $\$ 6.140,58$ & $\$ 2.274,04$ & $\$ 8.858,49$ & $\$ 2.940,22$ & $\$ 526,16$ & $\$ 358,92$ \\
\hline 2011 & $\$ 5.404,55$ & $\$ 4.697,59$ & $\$ 15.138,80$ & $\$ 2.670,45$ & $\$ 2.142,89$ & $\$ 999,23$ \\
\hline $\begin{array}{l}\text { Average 1989- } \\
1990\end{array}$ & & $\$ 553,81$ & $\$ 49,50$ & $\$ 0,01$ & & \\
\hline $\begin{array}{l}\text { Average 1990- } \\
1995\end{array}$ & $\$ 1.361,20$ & $\$ 2.031,84$ & $\$ 1.395,67$ & $\$ 161,84$ & $\$ 1.007,15$ & $\$ 122,89$ \\
\hline $\begin{array}{l}\text { Average 1996- } \\
2000\end{array}$ & $\$ 3.552,21$ & $\$ 3.375,55$ & $\$ 6.504,10$ & $\$ 1.118,56$ & $\$ 733,59$ & $\$ 193,40$ \\
\hline $\begin{array}{l}\text { Average 2001- } \\
2006\end{array}$ & $\$ 6.386,15$ & $\$ 4.643,21$ & $\$ 9.530,45$ & $\$ 4.796,70$ & $\$ 3.006,23$ & $\$ 725,47$ \\
\hline $\begin{array}{l}\text { Average 2006- } \\
2011\end{array}$ & $\$ 6.138,23$ & $\$ 4.352,31$ & $\$ 15.822,02$ & $\$ 7.608,61$ & $\$ 2.603,87$ & $\$ 801,89$ \\
\hline
\end{tabular}




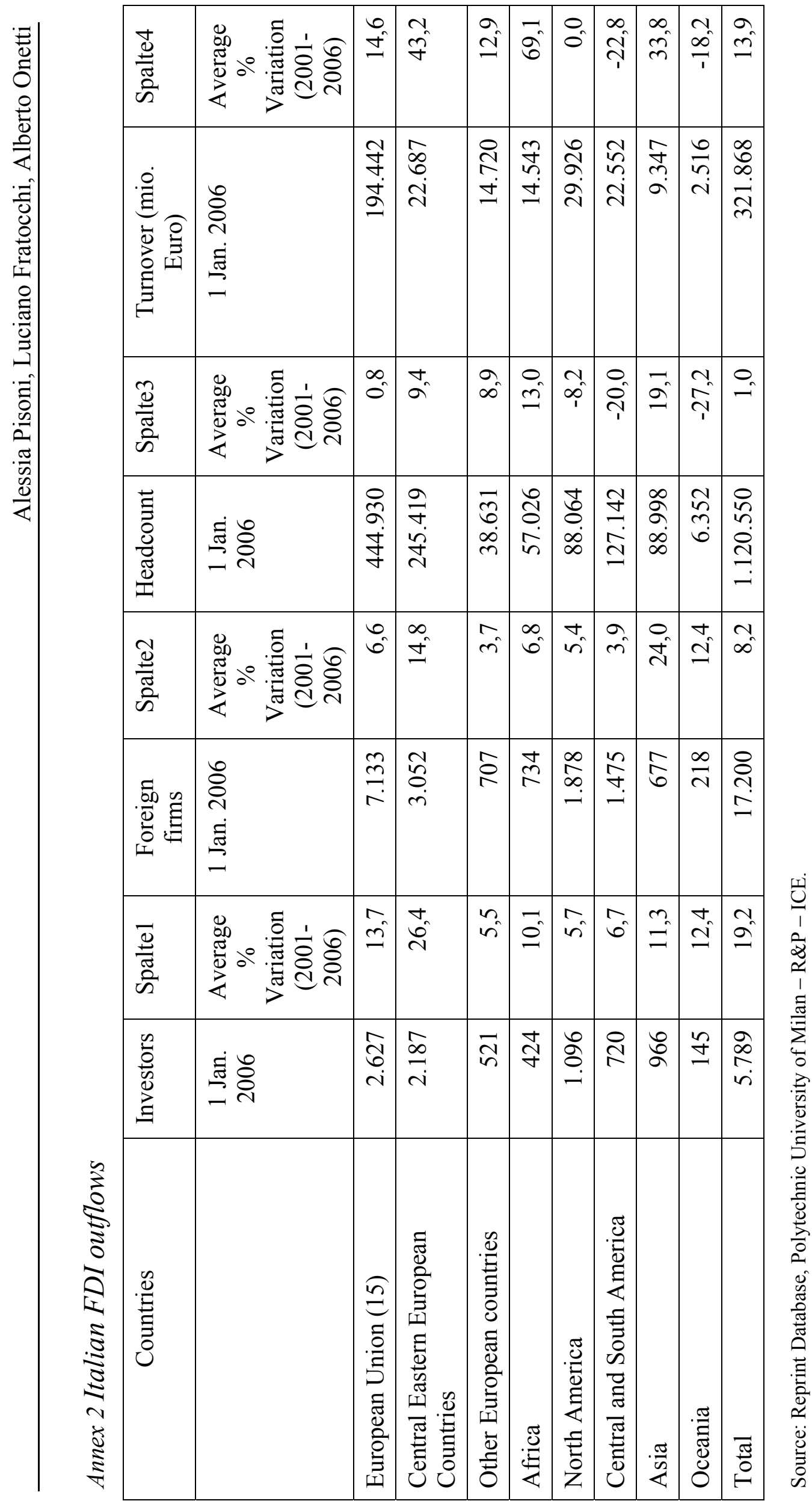




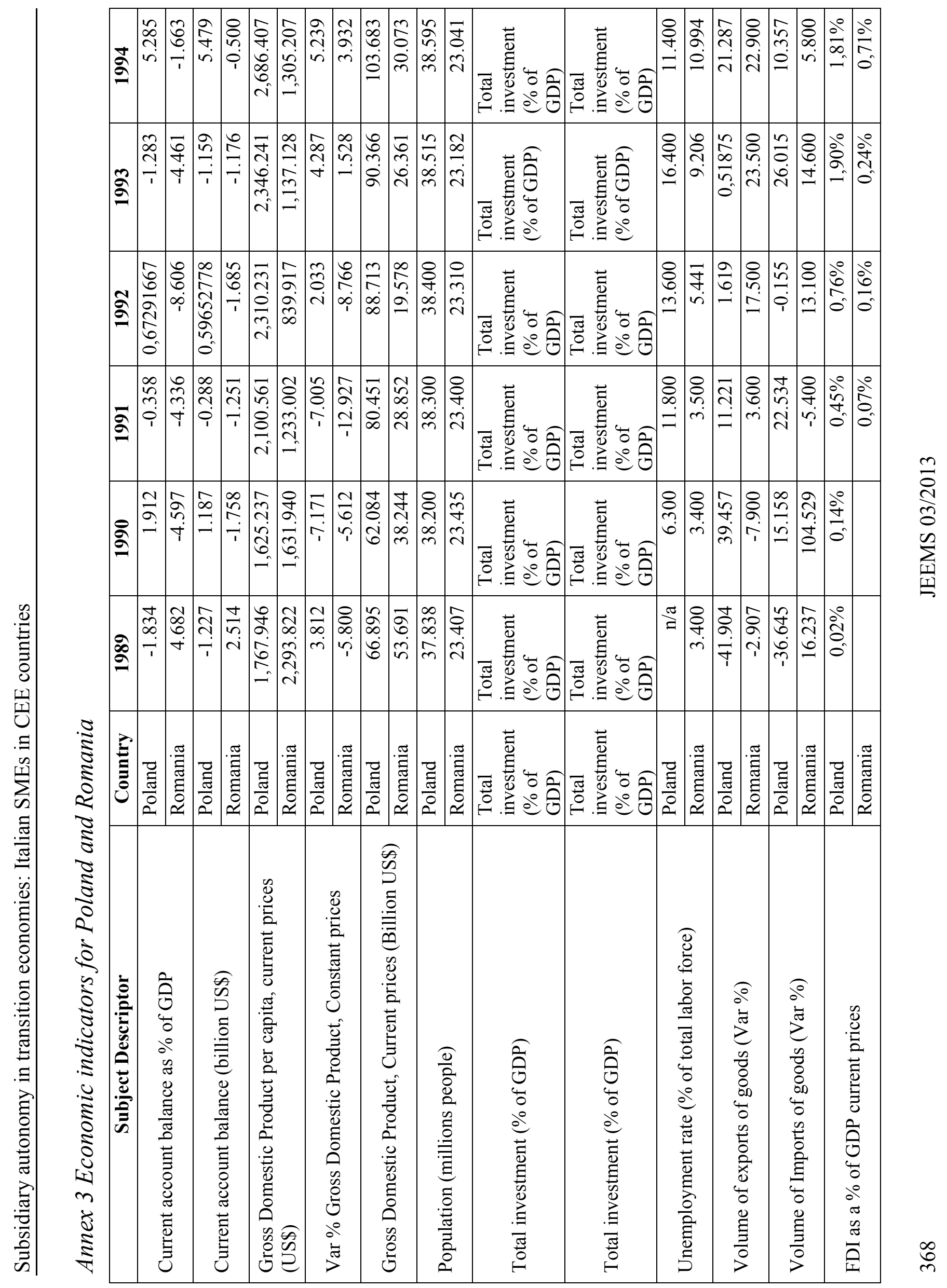




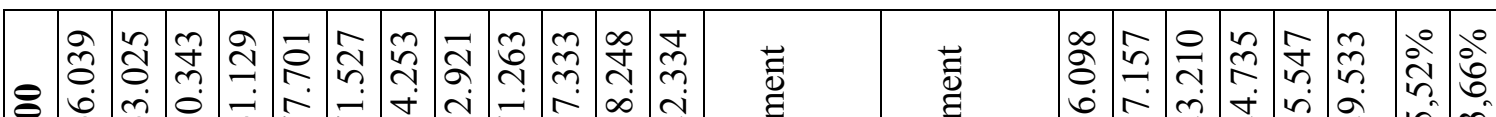

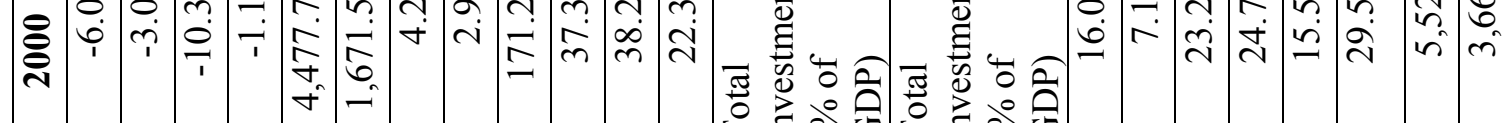

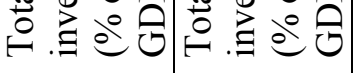

寺

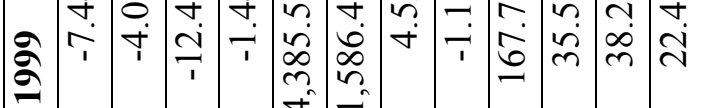

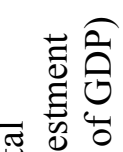

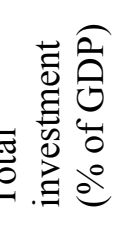

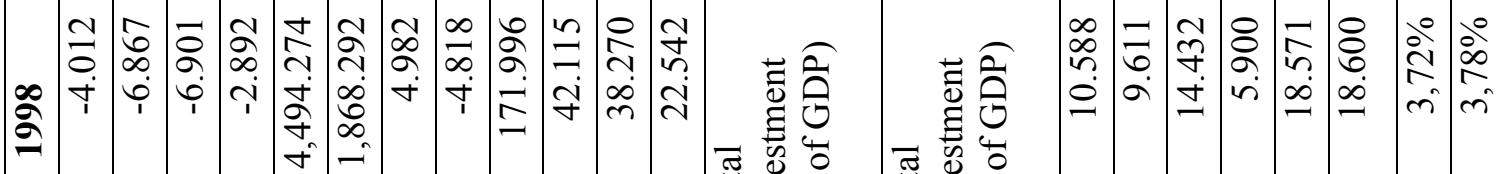

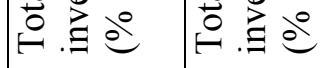

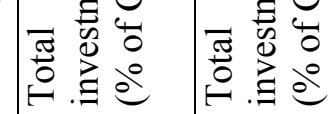

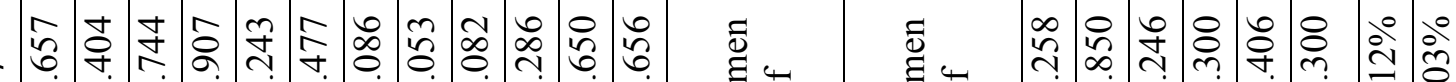

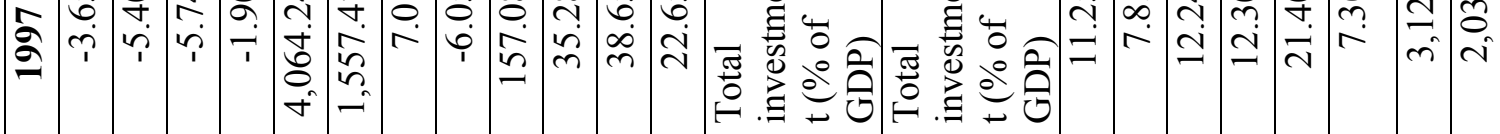

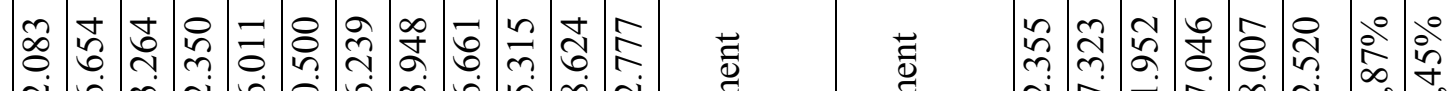
ڤે

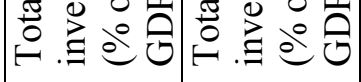

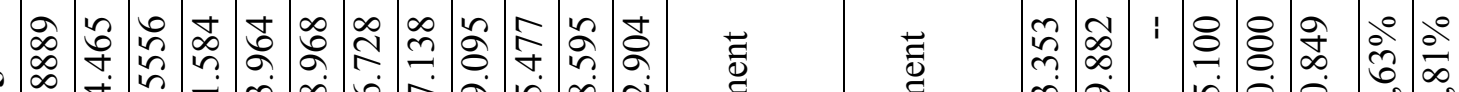

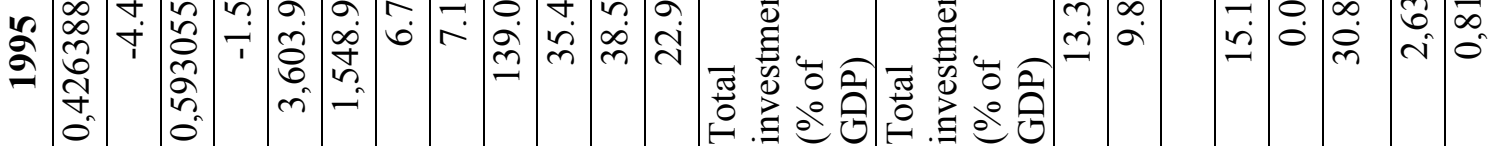

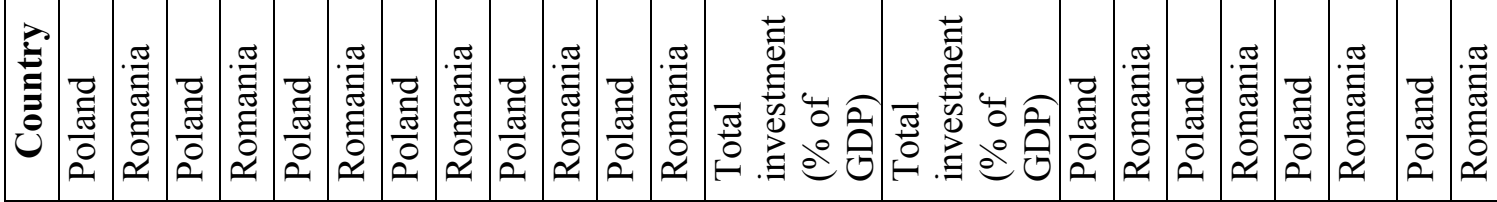

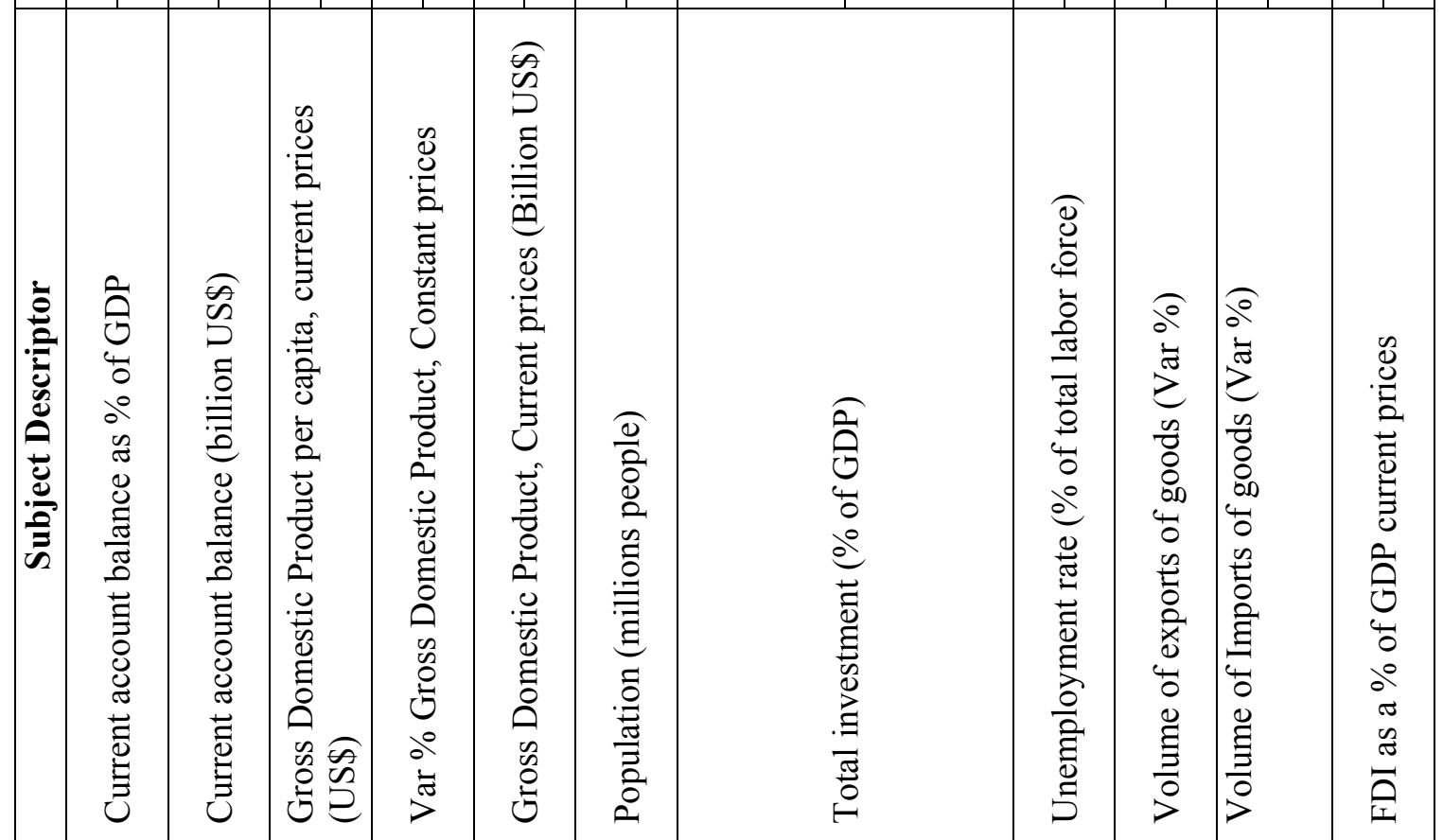

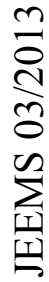




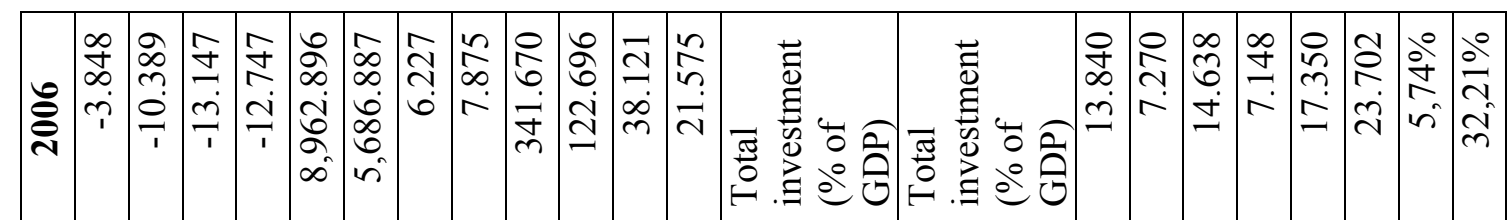

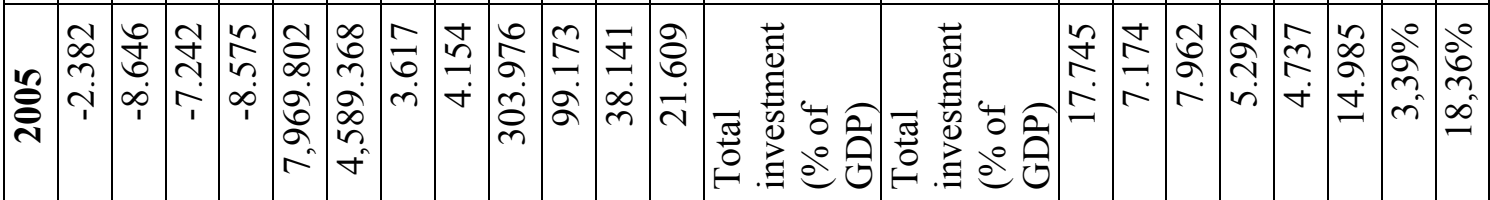

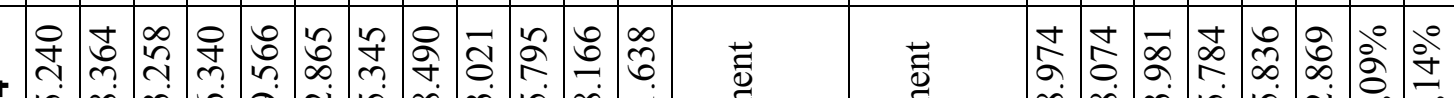

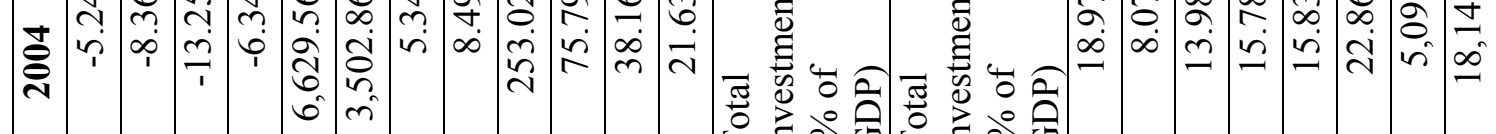

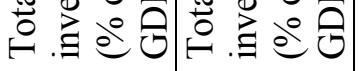

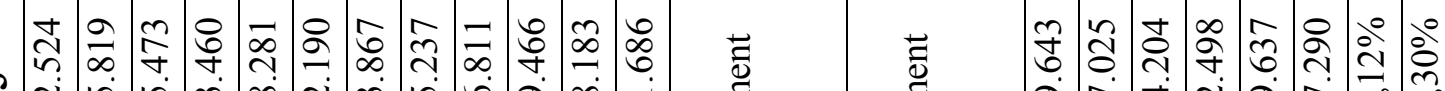

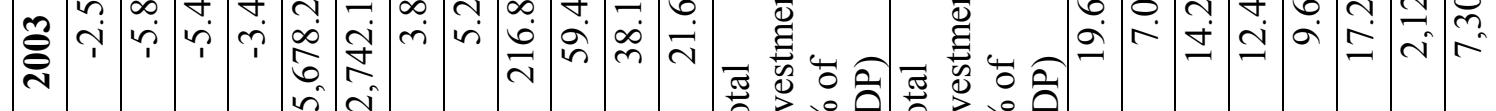
的的

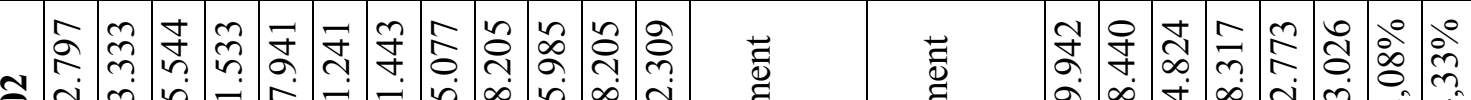

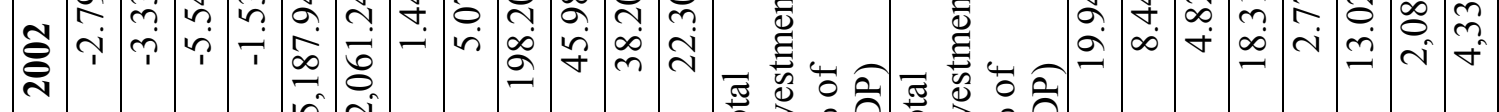

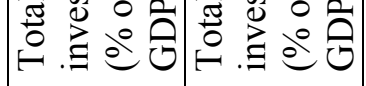

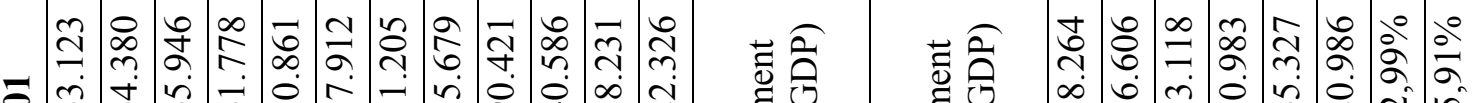

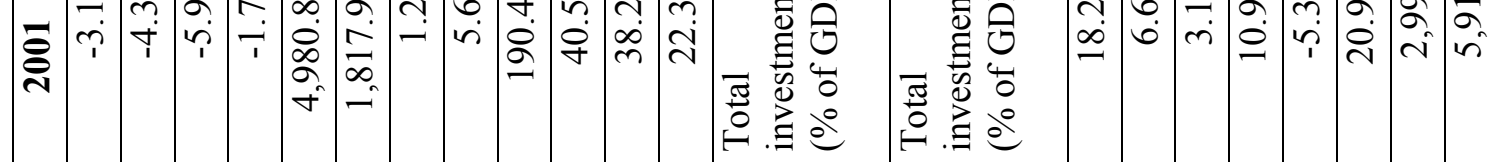

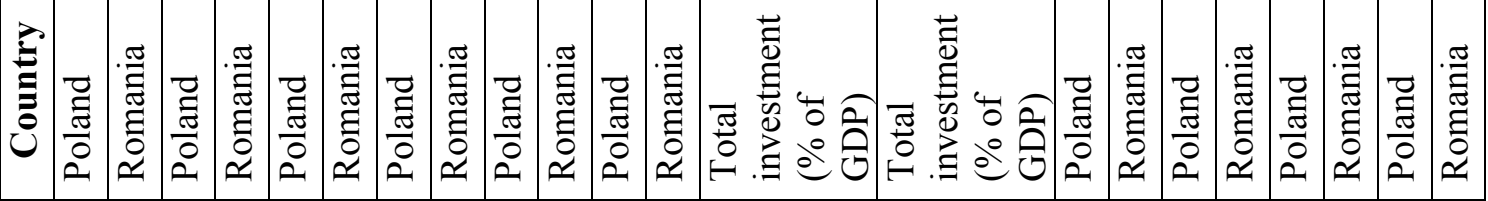

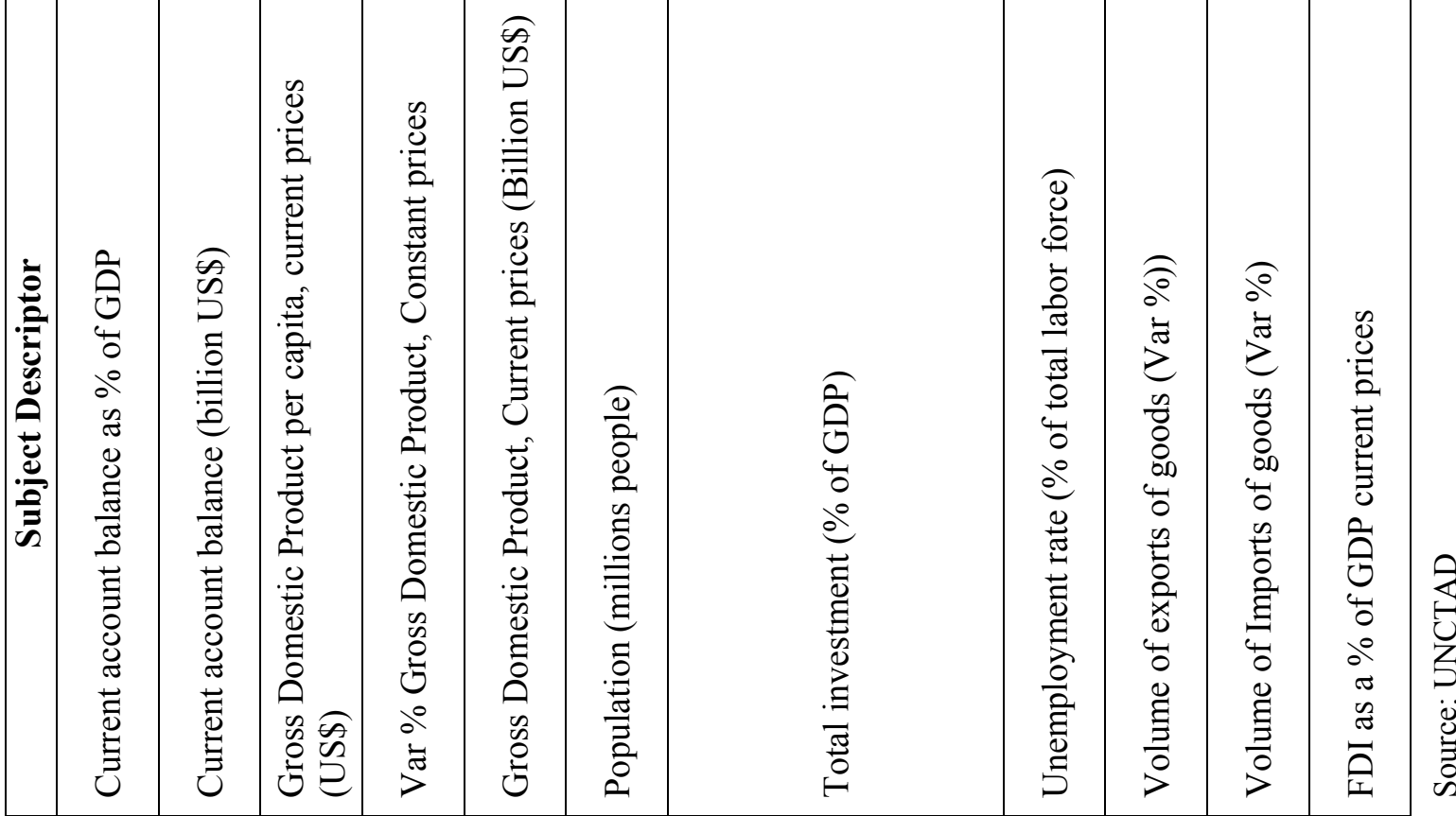

